This item was submitted to Loughborough's Research Repository by the author.

Items in Figshare are protected by copyright, with all rights reserved, unless otherwise indicated.

\title{
Time-step analysis of the DECC 2050 calculator pathways
}

PLEASE CITE THE PUBLISHED VERSION

http://dx.doi.org/10.1177/0957650917704993

\section{PUBLISHER}

SAGE @ IMechE

\section{VERSION}

AM (Accepted Manuscript)

\section{PUBLISHER STATEMENT}

This work is made available according to the conditions of the Creative Commons Attribution-NonCommercialNoDerivatives 4.0 International (CC BY-NC-ND 4.0) licence. Full details of this licence are available at: https://creativecommons.org/licenses/by-nc-nd/4.0/

\section{LICENCE}

CC BY-NC-ND 4.0

\section{REPOSITORY RECORD}

Barton, John P., Eoghan McKenna, and Murray Thomson. 2019. "Time-step Analysis of the DECC 2050 Calculator Pathways". figshare. https://hdl.handle.net/2134/22986. 
Institute of Mechanical Engineers, Part A: Journal of Power and Energy, special issue.

\section{Time-Step Analysis of the DECC 2050 Calculator Pathways}

John Barton ${ }^{a *}$, Eoghan McKenna ${ }^{a, b}$, Murray Thomson $^{a,}$

a Centre for Renewable Energy Systems Technology, School of Mechanical, Electrical and Manufacturing Engineering, Loughborough University, Loughborough. LE11 3TU. UK

b Environmental Change Institute, School of Geography and the Environment, University of Oxford, OX1 3QY

* Corresponding author

John Barton

CREST (Centre for Renewable Energy Systems Technology)

Wolfson School of Mechanical, Electrical \& Manufacturing Engineering

Holywell Park

Loughborough University

Loughborough

LE11 3TU

United Kingdom

Tel: +44 (0) 1509635350

E-mail: j.p.barton@lboro.ac.uk

Copies of FESA analysing each of the DECC 2050 Calculator pathways, and a copy of the Calculator, version 3.4.6 will be stored on the Loughborough University Repository, https://dspace.lboro.ac.uk/dspace-jspui/

DOI: 10.17028/rd.Iboro.4742905 


\section{Abstract}

An hour-by-hour time-step analysis is presented of United Kingdom (UK) electricity grid balancing in low-carbon energy pathways from the DECC 2050 Calculator. The detailed modelling uses the Future Energy Scenario Assessment (FESA) tool, which uses real weather data and real electricity demand data from year 2001 to model future supply and demand profiles, suitably adjusted to reflect technology uptakes. The paper describes the linking of the DECC 2050 Calculator with FESA and many of the detailed considerations within the modelling. The calculation of net demand (total demand less intermittent renewables and inflexible portions of other electricity generation) reveals the magnitude and duration of peaks and troughs throughout the year and this allows quantification of required peaking plant, energy storage, demand response or a combination of these. The results indicate that the grid balancing challenge is much greater than is apparent from the DECC 2050 Calculator, with significant excess power from renewables and less flexible generators needing to be exported or curtailed, and, at other times of the year, a significant amount of additional conventional generation being required. FESA also indicates significantly lower capacity factors for despatchable generators than indicated in the DECC 2050 Calculator. The results underline the value of energy storage and flexible demand, particularly in the high-renewables pathways, but also that much of that storage and flexibility needs to be available for days or even weeks rather than hours.

Keywords: low carbon transition pathways; scenarios; renewable energy; demand side management; energy storage; grid balancing; energy security; time step modelling; model integration 


\section{Introduction}

Intermittent renewable sources of electricity generation and inflexible nuclear power present a challenge to electricity systems in their balancing of supply with demand. As the UK moves to reduce greenhouse gas emissions in line with its obligations $(1,2)$, these low-carbon generators are likely to be increasingly used, and so the challenge of grid balancing will increase.

This paper describes the linking of the Future Energy Scenario Assessment (FESA) model with the DECC 2050 Calculator (3) and the use of the combined models to investigate the challenges of balancing the DECC 2050 scenario pathways on an hourly basis throughout a full year. Both these models have been used within the Transition Pathways project, (4) and their linking draws on the methodology of (5) by recognising the areas of overlap and complementarity of different models.

The DECC 2050 Calculator has been widely used to explore and visualise possible futures of UK energy supply and demand (3,6-8). Among its strengths are that it includes all significant uses of energy in the UK economy, it represents all significant sources of greenhouse-gas emissions and it estimates costs; it is also user-friendly and open-source leading to widespread use. Its outputs include quantification of the annual production and annual consumption of electricity and it is configured to ensure that these figures balance on an annual-energy basis. Of course in practice, the temporal availability of wind, solar and other renewables will not align with the temporal profile of demand, and whilst the DECC 2050 Calculator includes a general 
representation of energy storage and peaking plant, the detailed quantification of these is beyond its scope.

Future Energy Scenario Assessment (FESA) is a UK grid-balancing model developed at Loughborough University and presented previously $(6,7,9)$. Its strength is that it uses hourly data to represent a whole year of operation and so it can reveal the scale of the grid balancing challenge and provide quantification of required peaking plant, energy storage, demand response or the combination of these. It uses real weather data and real electricity demand data from year 2001 to model future supply and demand profiles, modelling the magnitude and duration of peaks and troughs in net demand (total demand less intermittent renewables and inflexible portions of other electricity generation).

The roles of despatchable generation, energy storage and demand shifting are investigated and presented against quantified indicators including curtailed (wasted) generation and unsatisfied demand. The resulting outputs also include electricity generated and used by each technology in each hour of the year. From these, the capacity factors (utilisation factors) of each form of controllable generation are calculated.

FESA models electricity demand in detail and non-electric energy use more simply, whereas the DECC 2050 Calculator models greenhouse gas (GHG) emissions and non-electric energy use in more detail.

Although data from year 2001 is now quite old, it was used because concurrent data from that year is available for electricity demand and all the forms of renewable 
energy modelled, and to be consistent with previous papers published using FESA $(6,7,9)$.

\section{Modelling details and assumptions}

Both models are written in Microsoft Excel and their linking allows a user to adjust inputs to the DECC 2050 Calculator, for example to consider a new scenario pathway, and for those modifications to automatically feed through to FESA and update its outputs. An overview of the data flows is shown in Figure 1 and is described in the following section.

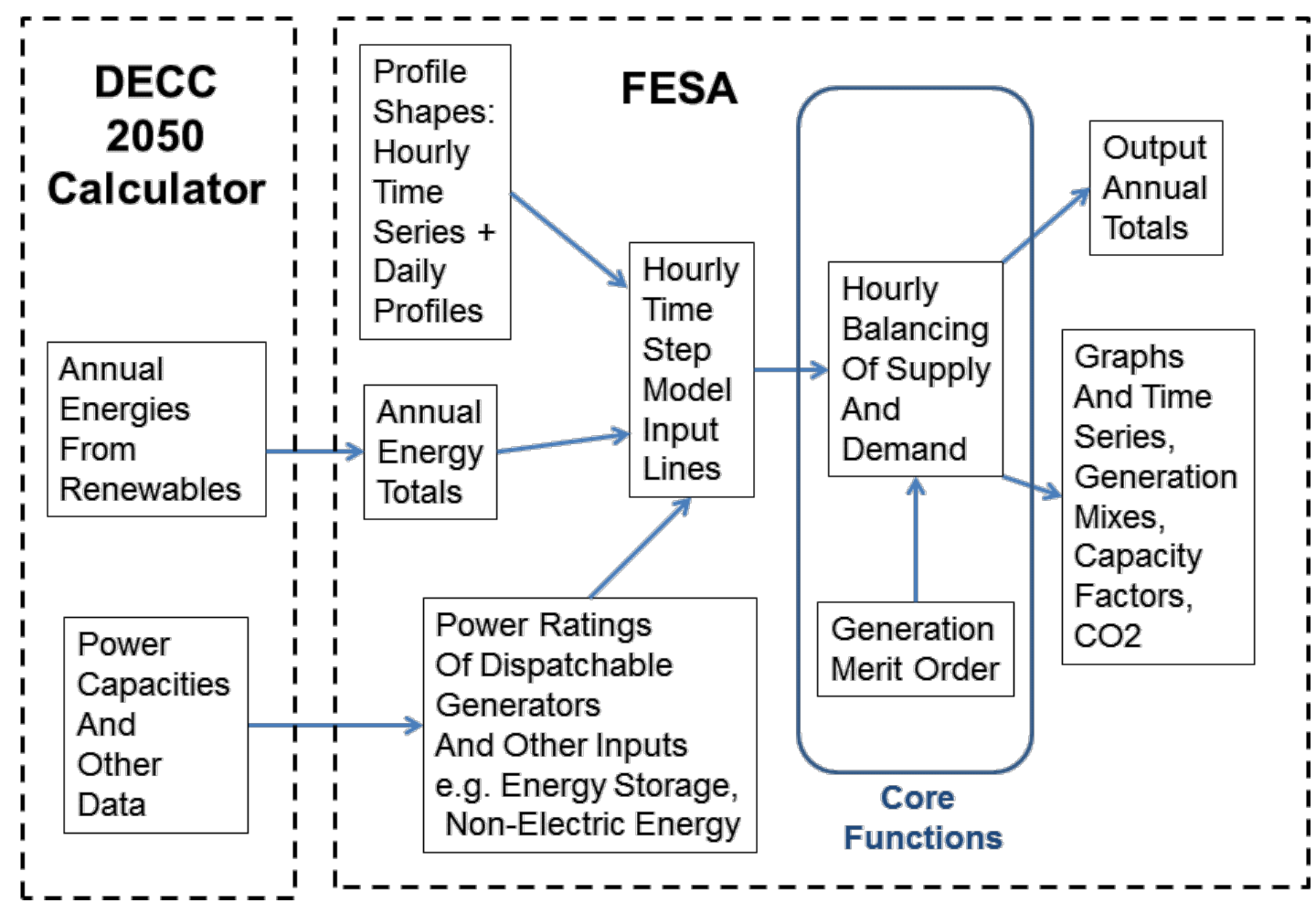

Figure 1. Overview of data flows from the DECC 2050 Calculator and through FESA

The annual energy production and consumption figures provided by the DECC 2050 Calculator are used as input data. FESA then applies hourly profiles and time series to these annual totals. An important feature of FESA is that, where appropriate, the hourly profiles are based on weather data from around the UK. Lists of the 
"uncontrollable" components of electricity generation and demand are given in tables A.1 and A.2 of the appendix, together with the source of data for the time series or profiles.

In order to be consistent with the DECC 2050 Calculator, FESA is configured to model the UK as a whole, including Northern Ireland. This is equivalent to assuming that Northern Ireland is very strongly electrically connected to the GB grid, which is not the case today and is may well not be the case in 2050. Nonetheless, it is a useful simplification for the purposes of this paper, since it allows direct comparison back to the DECC 2050 Calculator. Furthermore, configuring FESA to use GB-only data would not provide any different insight or conclusions overall. FESA is a singlenode model: it assumes unconstrained power flows throughout the UK.

The core functions of FESA are illustrated in Figure 2 and have been reported previously $(6,7,9)$. The inflexible, variable and uncontrolled portions of electricity generation are subtracted from the total electricity demand, as illustrated in Figure 2, to give a net demand that must be met by flexible sources of power. FESA first considers meeting the net demand using energy storage and "controllable" demands such as electric vehicle charging, as described in Table 1. FESA then uses conventional, despatchable generation in merit order to achieve grid balancing. 


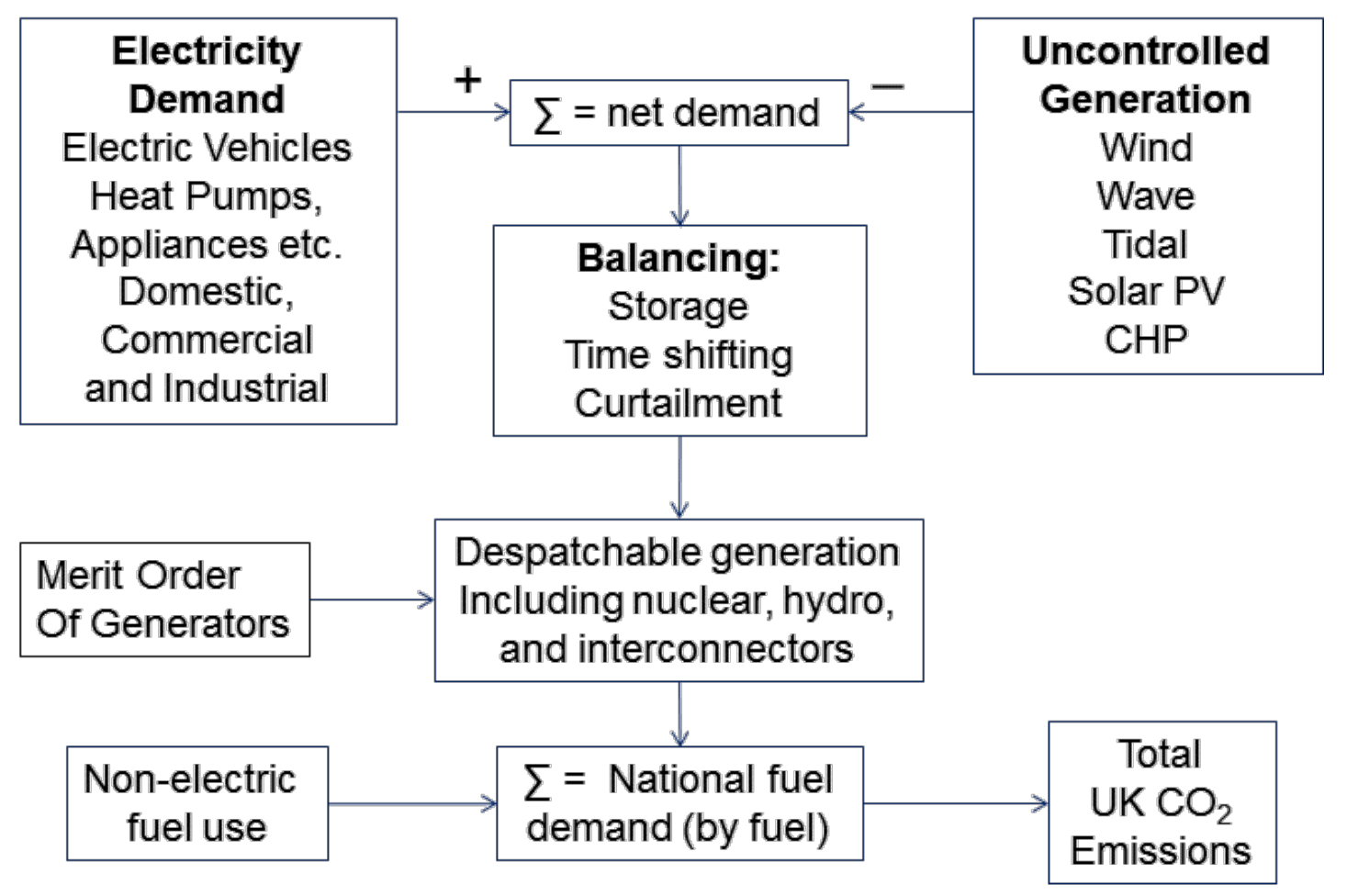

Figure 2. Overview of core functions of FESA model.

\subsection{Annual Total Quantities}

As far as possible, FESA takes all its inputs directly and automatically from the Excel version 3.4.6 of the DECC 2050 Calculator (10) and faithfully reproduces the annual total numbers. FESA has to use some assumptions to fill in gaps in the DECC data, and also make a few adjustments to be consistent with other input numbers. For example, domestic and commercial water heating demand are added together into a single number in FESA; and the annual average temperature rise due to climate change is calculated by averaging the expected temperatures in all four seasons in each year as given by the DECC 2050 Calculator.

The FESA inputs taken from the DECC 2050 Calculator are listed in appendix 4.

\subsection{Application of Profiles to Annual Totals}

Each form of variable renewable electricity generation and each component of electricity demand follows its own weather-related or daily (non-weather related) 
profile as described in appendices 1,2 and 3. In each case FESA applies the relevant profile to the annual total quantity given by the DECC Calculator. Consistency is confirmed within FESA by the annual summation of hourly values. For intermittent electricity generating technologies such as wind and solar PV, this summation is an annual total electrical energy, whereas for heat quantities, e.g. domestic space heat demand or CHP heat output, a total annual heat energy is confirmed. FESA also calculates the necessary installed capacity of each variable or inflexible generator to achieve the annual total, given the annual capacity factor of each form of generation. Generators falling into the category of 'uncontrolled generator' consist of: onshore wind, offshore wind, solar photovoltaics (PV), solar thermal water heating, domestic combined heat and power (CHP), commercial CHP, wave power, tidal stream and tidal barrage.

The time series of variable renewable energy sources were created using hourly weather records (11) but the time series of electricity demand was based on halfhourly electricity demand data from National Grid in the same year (12). Other profiles have to be estimated since their technology is not in widespread use, for example electric vehicle charging, heat pumps, and CHP.

\subsection{Heat Energy Demand}

Within electricity demand, FESA includes detail on heat-related energy use, with commercial heating and cooling energy use separated out from domestic energy use. Industrial uses of energy remain undifferentiated, being part of 'other electricity demand' which also includes domestic and commercial lighting and appliances. FESA concentrates on sectors with the best understood and greatest potential for demand-shifting (i.e. time-shifting of demand, not demand reduction). 
Industrial CHP is present in both the FESA model, and the DECC 2050 calculator, but is not explicitly modelled in either. Both DECC and FESA's industrial electricity demand is net of this electricity, which is accounted as industrial self-generation. Both models account the fuel used in industrial CHP as part of industrial fuel use. Looking at other sources of data, industrial CHP provides a large amount of heat for low, medium and high-temperature industrial processes (13). The electricity is produced as a by-product and typically used entirely within the industrial site. The demand profiles of industrial CHP are not easily accessible, but are largely independent of weather-related factors such as external temperature and largely inflexible. Industrial CHP is therefore not presently adjustable or useful for grid balancing, and FESA was not significantly diminished by the lack of an explicit model of it.

In contrast, domestic and commercial CHP provides low temperature heat for space heating and hot water. The use of this CHP is dependent on external temperature and in theory is amenable to adjustment or time-shifting in conjunction with lowtemperature heat stores. Profiles of domestic and commercial CHP are related to hot water demand and external temperature, and are better known. These sectors of CHP are therefore included in both FESA and the DECC 2050 Calculator.

In this study, FESA was run to faithfully reproduce the DECC 2050 Calculator example pathways, and therefore excluded the possibility of time-shifting domestic and commercial CHP. If time-shifting were included together with hot water storage, and if households can accommodate a hot water cylinder of 100 litres, cycling through a temperature range of $20^{\circ} \mathrm{C}$ to $80^{\circ} \mathrm{C}$, the heat storage capacity will be $7 \mathrm{kWh}$ 
per house. If half of the 40 million households in 2050 could accommodate a hot water cylinder, this would add 140GWh of thermal storage.

This thermal energy stored in hot water cylinders would translate into tens of GWh of flexible electricity supply (from CHP) and flexible demand (from heat pumps), which are comparable magnitude to either pumped hydro or electric vehicle charging, but not modelled by the DECC 2050 Calculator.

\subsection{Transport Energy Demand}

Battery electric vehicle charging was another sector of electricity demand that was modelled in detail. This sector includes both purely electric vehicles (EVs) and plugin hybrid electric vehicles (PHEVs). In the absence of extensive data on when EVs and PHEVs are really charged, a charging profile was created for FESA. This was based on the times of day when cars are parked, but modified to avoid electricity use at the peak demand time of early evening, in accordance with projections of future policy to aid grid balancing $(1,14-16)$. It was assumed that EV charging would take place primarily at night-time, for example in response to simple time-of-use tariffs.

FESA assumes both 'simple' and 'smart' demand shifting to aid grid balancing. Simple demand shifting means that the default profiles of demand are flatter or use more electricity at night and less during peak periods, as might result from time-ofuse tariffs, for example the default profile of EV charging described above, which was used up to and including year 2015. Smart demand shifting is more flexible and is modelled as a form of energy storage, as described below in Section 2.5. Smart meters are assumed to be ubiquitous from 2020 onwards in accordance with government policy (17-20), and this is interpreted as including the use of flexible 
demand, mainly electric vehicle charging, which was treated as a form of smart demand shifting from year 2020 onwards.

\subsection{Energy storage and time-shifting of demand}

The 'Electricity distribution, storage and balancing' section of the DECC 2050

Calculator is rather limited. FESA faithfully reproduces the flexible demand modelled in the DECC 2050 Calculator, which consists only of time-shifting of electric vehicle charging. The DECC 2050 Calculator balancing section also contains international interconnection, extra 'boostable' generating capacity and pumped storage, again, faithfully modelled by FESA. Whereas the DECC 2050 Calculator only considers peak demand and availability factors, FESA goes much further by considering the duration for which peak net demand persists, and also periods of electricity surplus.

Recognising that most forms of time-shifting flexible demand involve inbuilt energy storage, FESA models demand shifting as a form of energy storage. For simplicity, all types of storage and time-shifting are aggregated together into one large national energy store, and are assumed to operate over 24 hours only. The net demand in each hour is compared with a 24-hour moving average of net demand calculated 12 hours before the hour and 12 hours after the hour, including the hour itself. 24 hours was chosen as the averaging period and as the maximum working energy storage period because:

(i) The natural variations in demand and in solar, wind and tidal generation include significant or dominant cycles on a daily or almost daily basis.

(ii) The storage associated with time-shifting mechanisms available to the electricity system have a time constant appropriate to 24-hour storage. 
Existing pumped hydro has an energy-to-power ratio of 9.3 hours and electric vehicles are designed to be charged up overnight, typically over a period of 7 hours.

Note that a store performing sinusoidal cycles of power and energy requires an energy-to-power ratio (time constant) equal to the storage period divided by $\pi$ (3.14), so a period of 24 hours requires a store with a time constant of about 7.6 hours. FESA used the same power ratings as the DECC 2050 Calculator for its energy storage and flexible demand modelling, Table 1, but FESA then estimated the energy rating associated with each power rating.

Note that when the grid balancing measures are set to effort level 4 in the DECC 2050 Calculator, the power rating of pumped hydro is $20 \mathrm{GW}$. Whereas the Calculator then assumes an energy rating of 400GWh, FESA assumes an energy rating of $186.7 \mathrm{GWh}$, maintaining today's energy-to-power ratio of 9.3. These levels of power and energy are considered ambitious by some but achievable by Prof. David MacKay whose work contributed to the DECC 2050 Calculator (21) and by others who have studied the possibility of converting conventional hydro power into pumped hydro (22).

Also note that in FESA, pumped hydro is still used on a daily basis, maintaining a high utilisation factor, even at the highest level of deployment. The use of longer timescales of storage is a promising area of research for future work. 
Table 1. Energy storage and demand time shifting resources

\begin{tabular}{|c|c|c|c|c|}
\hline Scenario & $\begin{array}{l}\text { Storage / Time- } \\
\text { shifting resource }\end{array}$ & $\begin{array}{l}\text { Energy } \\
\text { Capacity, } \\
\text { GWh }\end{array}$ & $\begin{array}{l}\text { Power } \\
\text { rating, GW }\end{array}$ & $\begin{array}{l}\text { Time } \\
\text { Constant, } \\
\text { Hours }\end{array}$ \\
\hline \multirow{2}{*}{ Year 2010} & Pumped Hydro & 26.7 & 2.86 & 9.3 \\
\hline & Electric Vehicles & 0 & 0 & 0 \\
\hline \multirow{2}{*}{$\begin{array}{l}\text { Markal } 3.26 \text { in Year } \\
2050\end{array}$} & Pumped Hydro & 37.3 & 4.0 & 9.3 \\
\hline & Electric Vehicles & 7.37 & 1.05 & 7.0 \\
\hline \multirow{2}{*}{$\begin{array}{l}\text { Higher Renewables } \\
\text { in Year } 2050\end{array}$} & Pumped Hydro & 186.7 & 20 & 9.3 \\
\hline & Electric Vehicles & 22.1 & 3.15 & 7.0 \\
\hline \multirow{2}{*}{$\begin{array}{l}\text { Higher Nuclear in } \\
\text { Year } 2050\end{array}$} & Pumped Hydro & 37.3 & 4.0 & 9.3 \\
\hline & Electric Vehicles & 9.46 & 1.35 & 7.0 \\
\hline \multirow{2}{*}{$\begin{array}{l}\text { Higher CCS in Year } \\
2050\end{array}$} & Pumped Hydro & 37.3 & 4.0 & 9.3 \\
\hline & Electric Vehicles & 7.52 & 1.07 & 7.0 \\
\hline \multirow{2}{*}{$\begin{array}{l}\text { Low Cost in Year } \\
2050\end{array}$} & Pumped Hydro & 32.7 & 3.5 & 9.3 \\
\hline & Electric Vehicles & 0 & 0 & 0 \\
\hline \multirow{2}{*}{$\begin{array}{l}\text { Friends Of the } \\
\text { Earth in Year } 2050\end{array}$} & Pumped Hydro & 186.7 & 20 & 9.3 \\
\hline & Electric Vehicles & 22.1 & 3.15 & 7.0 \\
\hline \multirow{2}{*}{$\begin{array}{l}\text { Campaign to } \\
\text { Protect Rural } \\
\text { England in } 2050\end{array}$} & Pumped Hydro & 65.3 & 7.0 & 9.3 \\
\hline & Electric Vehicles & 18.2 & 2.6 & 7.0 \\
\hline \multirow{2}{*}{$\begin{array}{l}\text { Mark Brinkley in } \\
\text { Year } 2050\end{array}$} & Pumped Hydro & 186.7 & 20 & 9.3 \\
\hline & Electric Vehicles & 28.3 & 4.05 & 7.0 \\
\hline \multirow{2}{*}{$\begin{array}{l}\text { National Grid in } \\
\text { Year } 2050\end{array}$} & Pumped Hydro & 37.3 & 4.0 & 9.3 \\
\hline & Electric Vehicles & 9.46 & 1.35 & 7.0 \\
\hline \multirow[t]{2}{*}{ Atkins in Year 2050} & Pumped Hydro & 65.3 & 7.0 & 9.3 \\
\hline & Electric Vehicles & 16.7 & 2.38 & 7.0 \\
\hline
\end{tabular}

The energy store control algorithm uses the difference between the net demand in each hour and the 24-hour moving average to smooth the net demand towards the 24-hour moving average and to reduce the size of peaks and troughs. The energy storage control strategy is also described in (23) but McKenna uses a reference price whereas FESA uses net demand. The control algorithm reduces the charging rate as the store approaches a full state and reduces its discharge rate as it approaches an empty state. It does this to avoid disturbances to the electricity system caused by suddenly becoming completely full or empty and the loss of usefulness of the store that either of these events would cause. 


\subsection{Generation Merit Order}

As illustrated in Figure 2, once energy storage and time-shifting of demand have been taken into account, the remaining net demand is that which must be met by conventional or controllable generation.

FESA allocates this on a merit-order basis, using four tiers approximately corresponding to carbon intensity, Figure 4. The least flexible low carbon generator outputs are calculated first (e.g. nuclear power), followed by the flexible low carbon generators (biomass or CCS), followed by the higher carbon (unabated fossil fuel), and then finally the least efficient and highest carbon-emitting generators (e.g. opencycle gas turbines).

\subsubsection{Less flexible low-carbon generators:}

There are four kinds of generation in the category of least flexible: Nuclear, hydro, geothermal and imports. The DECC 2050 Calculator model specifies an annual energy output for each of these types of generation (in TWh) as well as a maximum generating capacity (in GW). FESA therefore has to perform calculations to meet both these numbers for each type of generation. The inclusion of large hydro power in this category is a little anomalous since hydro can adjust its output from zero to full power over relatively short time frames. However, it is resource-limited by annual rainfall and has finite storage capacity. It has a relatively small contribution to total UK electricity generation, and is included here as a modelling simplification.

The inclusion of planned electricity imports in this category is also a little anomalous since imports are not necessarily low-carbon. Imports are treated as baseload generation in the DECC 2050 Calculator, and FESA aims to replicate its underlying assumptions as far as possible. Planned imports are limited by trading contracts. 
Nuclear power stations each have a minimum operational power output, and tend to operate continuously for many months followed by planned and unplanned outages that FESA cannot model. Geothermal power has an availability in the DECC 2050 Calculator, but one applying to the whole year causing it to have a constant power output. Each generator does a share of load following, within the limitations described above. This is done by a linear relationship to net demand, equation (1) but each type of generation is subject to physical constraints as described in equations (2), (3) and (4).

$P_{G}(t)=k D(t)+C$

Where

$P_{G}(t)$ is the total power output of generators of type $G$ in hour $t$

$D(t)$ is the net demand (demand - intermittent renewable supply) in hour $t$

$C$ and $k$ are constants

Subject to constraints:

$k D_{\text {Max }}+C \leq P_{G \operatorname{Max}}$

$k D_{\text {Min }}+C \geq 0$

$\frac{1}{T} \sum_{t=1}^{T}[k D(t)+C]=P_{G A v e}$

Where:

$D_{\text {Min }}$ and $D_{\text {Max }}$ are the annual minimum and maximum values of net demand 
$P_{G M a x}$ is the available maximum power from generators of type $G$

$P_{G A v e}$ is the annual average power from generators of type $G$

Each type of generation is controlled to maximise its usefulness for balancing supply and demand, in other words maximising their responsiveness to net demand. In mathematical terms, this means maximising the gradient, $\mathrm{k}$ in equation (1). Depending on the ratio of $P_{G A v e}$ to $P_{G M a x}$ and the distribution of net demand, $D$, this is achieved by one of the following control regimes:

$$
C \geq 0, \quad k D_{M a x}+C=P_{G M a x}
$$

for $P_{\text {GAve }}$ that is large relative to $P_{G M a x}$

$$
C=0, \quad k D_{M a x} \leq P_{G M a x}
$$

for $P_{\text {GAve }}$ that is small relative to $P_{\text {GMax }}$

Equations (5) and (6) are shown as graphs in Figure 3 parts (a) and (b) respectively. When using inputs from the DECC 2050 Calculator equation (5) is appropriate for nuclear and geothermal power (where present), whereas equation (6) is appropriate for rainfall-limited hydro power and planned imports of electricity. 
(a) A Baseload Generator With High Average Power

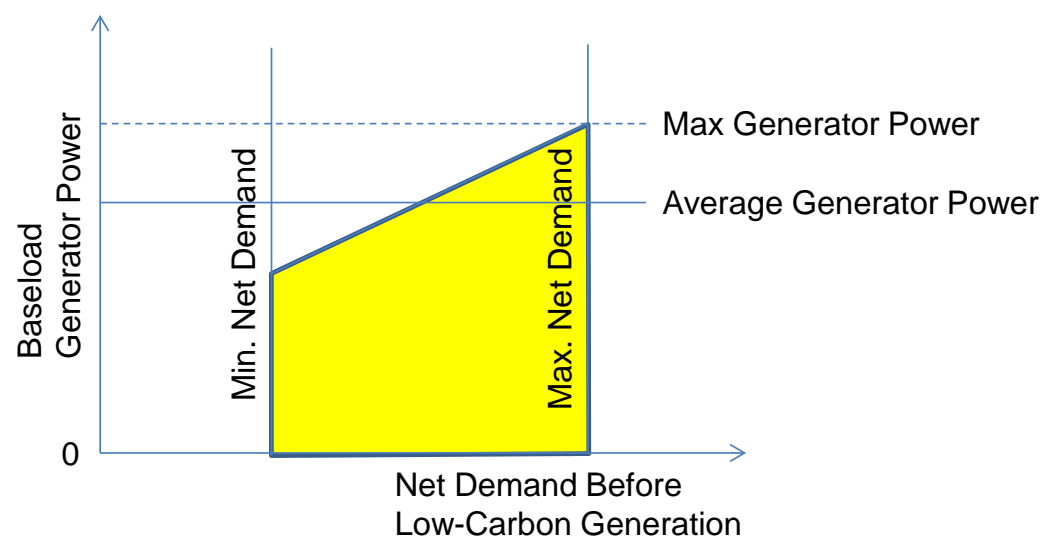

(b) A Baseload Generator With Low Average Power

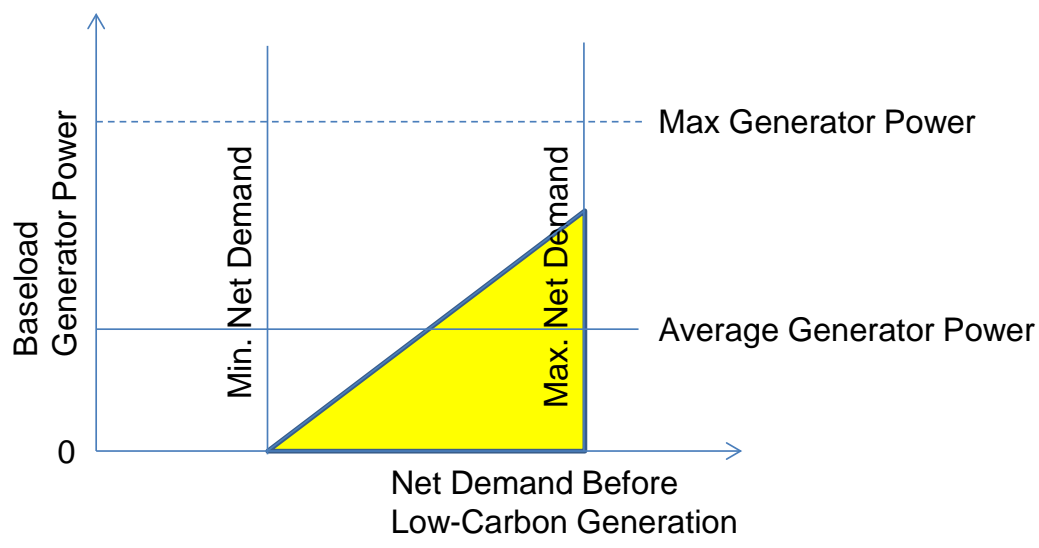

Figure 3. Calculation of less flexible generator powers (nuclear, hydro, geothermal or imports)

\subsubsection{More Flexible Low-carbon generators}

In FESA, the least flexible low carbon generators described above are constrained to have the same annual total as in the DECC 2050 Calculator version of the pathway but all other forms of generation described in this section and following sections are allowed to be different in total electricity demand as they respond to demand hourby-hour. More flexible low-carbon generators consist of biomass fuelled and CCS generators (coal or gas fired with CCS), which are lower carbon emitters than the older, unabated fossil fuel generators but are not entirely emission free, and they require fuel. Their position in the despatch merit order is therefore lower than the least flexible generators but higher than unabated fossil-fuelled generators. All three 
have equal position in the merit order. At any hour of the year, the output of these generators exists in one of three states:

1. When net demand is already fully satisfied by energy storage, load shifting and less flexible generation, their output is zero.

2. When net demand is less than their combined maximum available generating capacity, they share the load-following duty, in proportion to the available generating capacity of each.

3. When net demand exceeds their combined maximum available generating capacity, they each run at their maximum.

The installed capacities and characteristics of low-carbon generators are read from the relevant worksheet of the DECC 2050 Calculator, I.a for biomass, I.b for coal CCS and I.b for gas CCS.

\subsubsection{High-Carbon Generators}

These generators consist of unabated (i.e. without CCS) coal and gas fuelled generators using combined cycle gas turbines (CCGT). This tier of high-carbon generators only runs when the net demand exceeds the combined balancing capability of all the above balancing mechanisms and generators. High carbon generators then share the load-following duty with each other in the same way as low carbon generators, up to their combined maximum winter availabilities.

The installed capacities and characteristics of high-carbon generators are read from worksheet I.a of the DECC 2050 Calculator. 


\subsubsection{Peaking plant}

These consist of oil-fired generators and gas-fired generators using less efficient but quicker responding open-cycle gas turbines (OCGT). Again, these generators only operate when the net demand exceeds the combined capacity of all the above generators and balancing mechanisms, and they generate up to their maximum winter availabilities.

The installed capacities and characteristics of peaking plant come from two places: Oil-fired generation comes from DECC worksheet I.a but the gas-fired generation comes from the balancing worksheet, VII.c.

\subsubsection{Emergency import and export}

Any remaining shortfall or surplus of electricity is imported / exported if possible. This is in addition to the planned imports, and is only available up to the capacity of the interconnectors not used by the planned imports.

\subsubsection{Summary of merit order}

The merit order of measures to match supply with demand is shown below in Figure 4. 


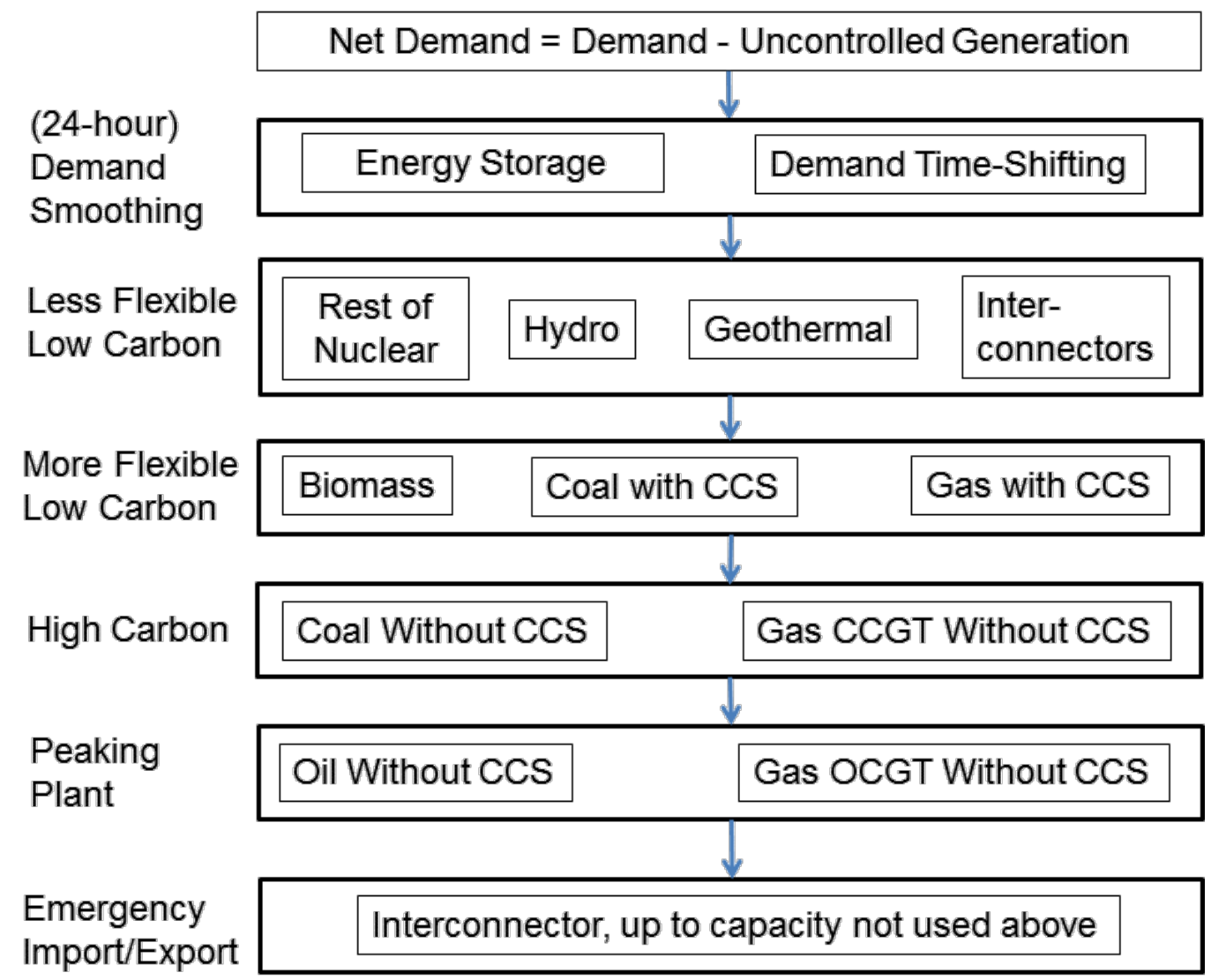

\section{Figure 4. Merit order of grid balancing}

\subsection{Pathways selected for study}

The DECC 2050 Calculator (3) models all energy use in the UK on an annual total basis in 2007, 2010 and then in 5 year steps to 2050 ensuring that annual energy supply matches energy use and losses at each stage of energy conversion. Demand is disaggregated into sectors approximately corresponding with the Digest of UK Energy Statistics (DUKES) with some further end-use disaggregation.

The DECC 2050 Calculator can of course model a huge variety of pathways to a low carbon economy, and even more potential pathways that fail to achieve an $80 \%$ reduction in greenhouse gas (GHGs) emissions by 2050. However, ten example lowcarbon pathways have been chosen that were provided with the online and downloadable versions of the calculator, and those are the ones studied and 
compared in this paper. These pathways are summarised for reference in the appendix. Four of these ten are 'Markal 3.26', 'Low Cost', 'Higher Renewables' and 'Friends of the Earth (FOE)' and are illustrative of the range of pathways.

\section{Results and Discussion}

The following graphs and tables show results of FESA time-step analysis. They reveal the extent of the grid balancing challenge in terms of unsatisfied demand and curtailed renewable generation. They also show that the DECC 2050 Calculator assumes high levels of capacity factor for fuelled generators and that this overestimates the amount of electricity needed from those generators.

The following sections describe these and other results in detail, comparing FESA analysis with the much simpler DECC 2050 Calculator results.

\subsection{Electricity Generation Despatch}

The use of less flexible low carbon generators in the first four days of January are shown in Figure 5. Nuclear power does a little load following but has almost constant power because its average level is close to its maximum level. In contrast, imported electricity and hydro power do more load following but at a lower average level. 


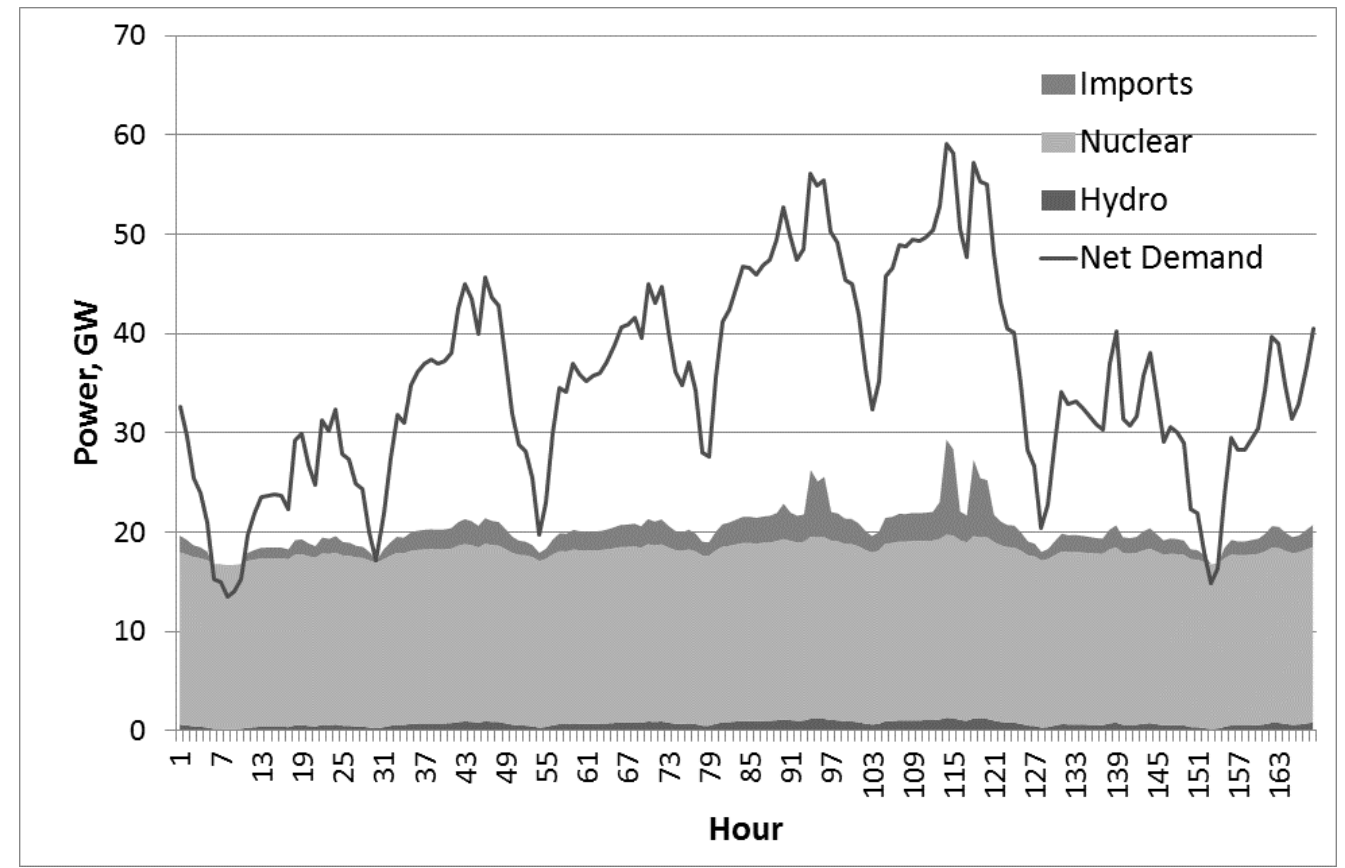

Figure 5. Less flexible low carbon generators during the first 4 days of January under the DECC Markal 3.26 scenario in year 2040. 


\subsection{Net Demand}

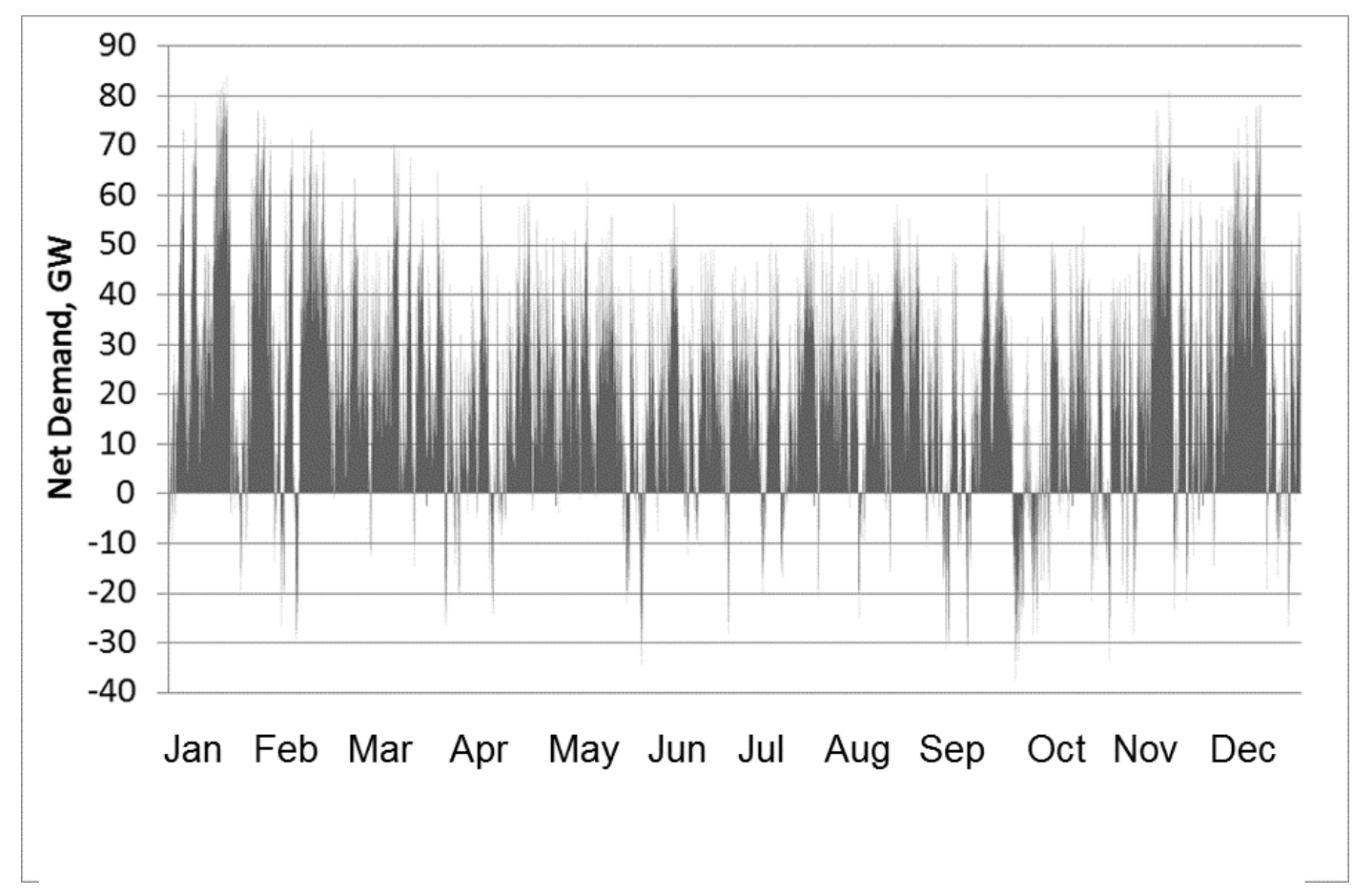

Figure 6. Net demand before energy storage and demand time shifting for the Higher Renewables pathway in 2050

A typical result from the FESA time-step model is shown in Figure 6. When total electricity demand is increased due to heat pumps and electric vehicle charging, the peaks of net demand are higher than in the UK today but then offset by intermittent renewable generation that acts as negative demand, creating troughs that are sometimes negative. Renewable generation and demand are very variable, making the peaks and troughs very spikey. However, periods of low renewable generation lead to peaks lasting 2 or 3 weeks, and periods of high renewable generation result in troughs, again lasting for 2 or 3 weeks. When arranged in order of net demand to create load duration curves, the curves for the DECC low carbon scenarios in 2050 are mostly much steeper than for the UK in 2010, Figure 7. 


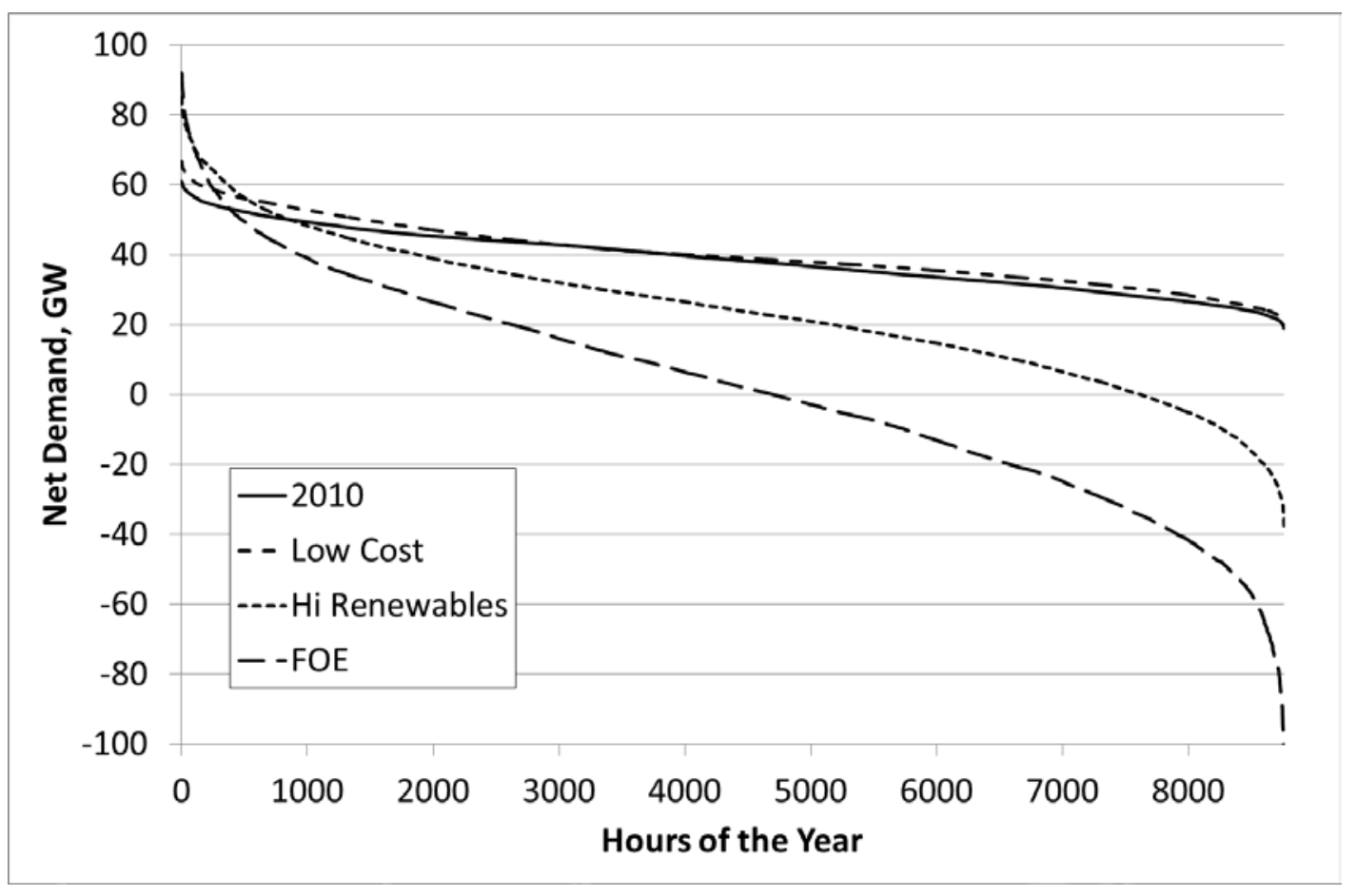

Figure 7. Net Demand Duration Curves for the UK in 2010 and under 3 lowcarbon scenarios in $\mathbf{2 0 5 0}$

Figure 7 shows the total variability of net demand of three extreme scenarios: a typical one (Higher Renewables), one that is difficult to balance (FOE) and the easiest to balance (Low Cost). These curves do not include the inflexible 'must run' portion of nuclear power, which would shift all the curves lower. Under the 'Low Cost' scenario in 2050 , the variability is only slightly greater than in 2010 , but even here, the peak demand is higher. In the 'Higher Renewables' scenario, the curve is much steeper, and goes negative (surplus power) for a significant portion of the year. The FOE scenario shows a surplus for nearly half the year. The overall picture is that the grid balancing challenge is considerably greater under most low-carbon scenarios.

\subsection{Energy Storage and Demand Shifting}

After energy storage and demand shifting are applied using the quantities shown in Table 1, the net demand variability is reduced under all scenarios. The Higher 
Renewables pathway in 2050 is shown again after storage and demand shifting in Figure 8.

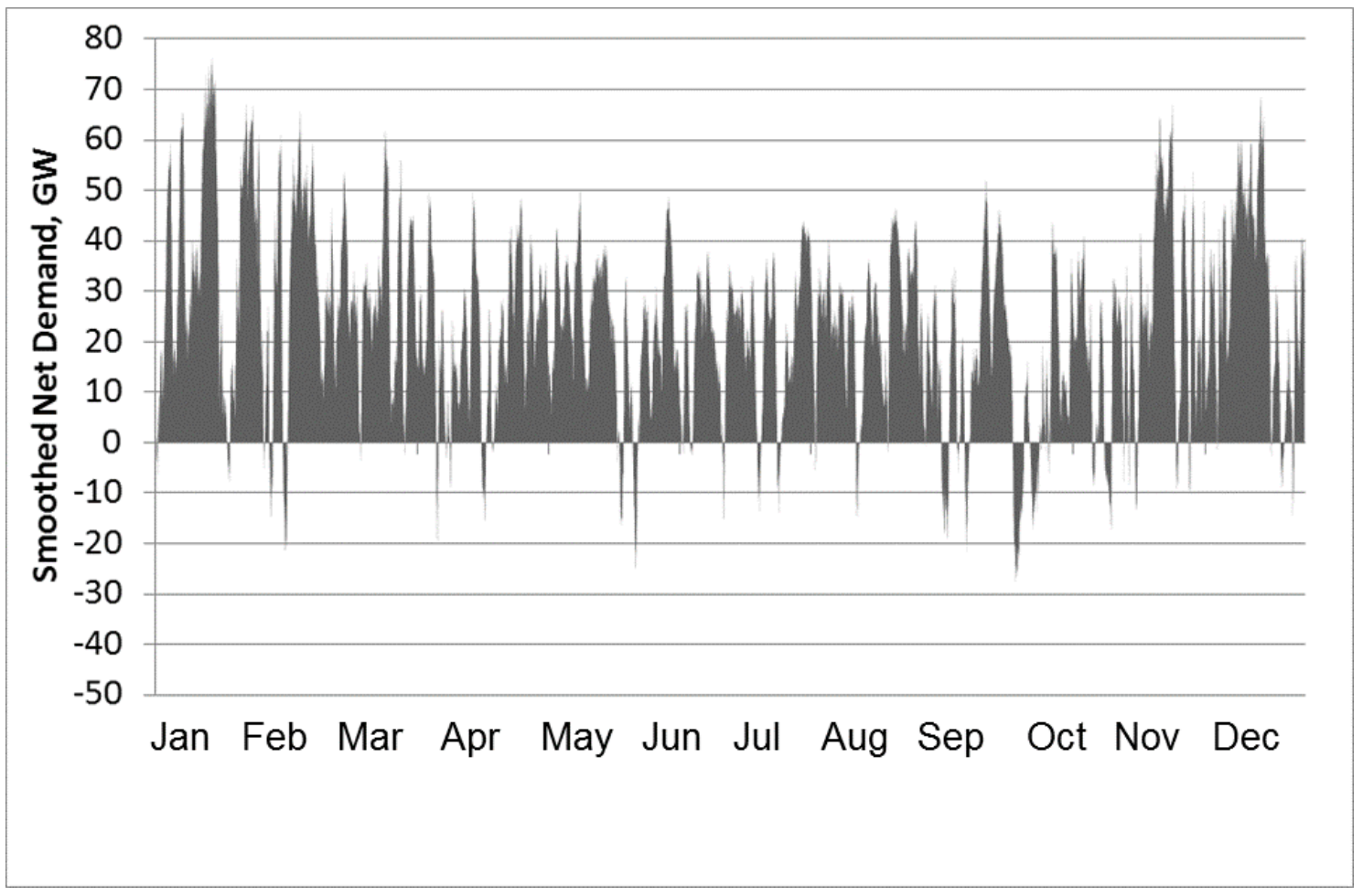

Figure 8. Higher Renewables pathway in 2050 after application of storage and time-shifting of demand

Figure 8 shows a reduction in the hour-to-hour variation in net demand and also a reduction in the extremity of peaks and troughs. These reductions are more easily seen by zooming in on a shorter period of time, Figure 9. 


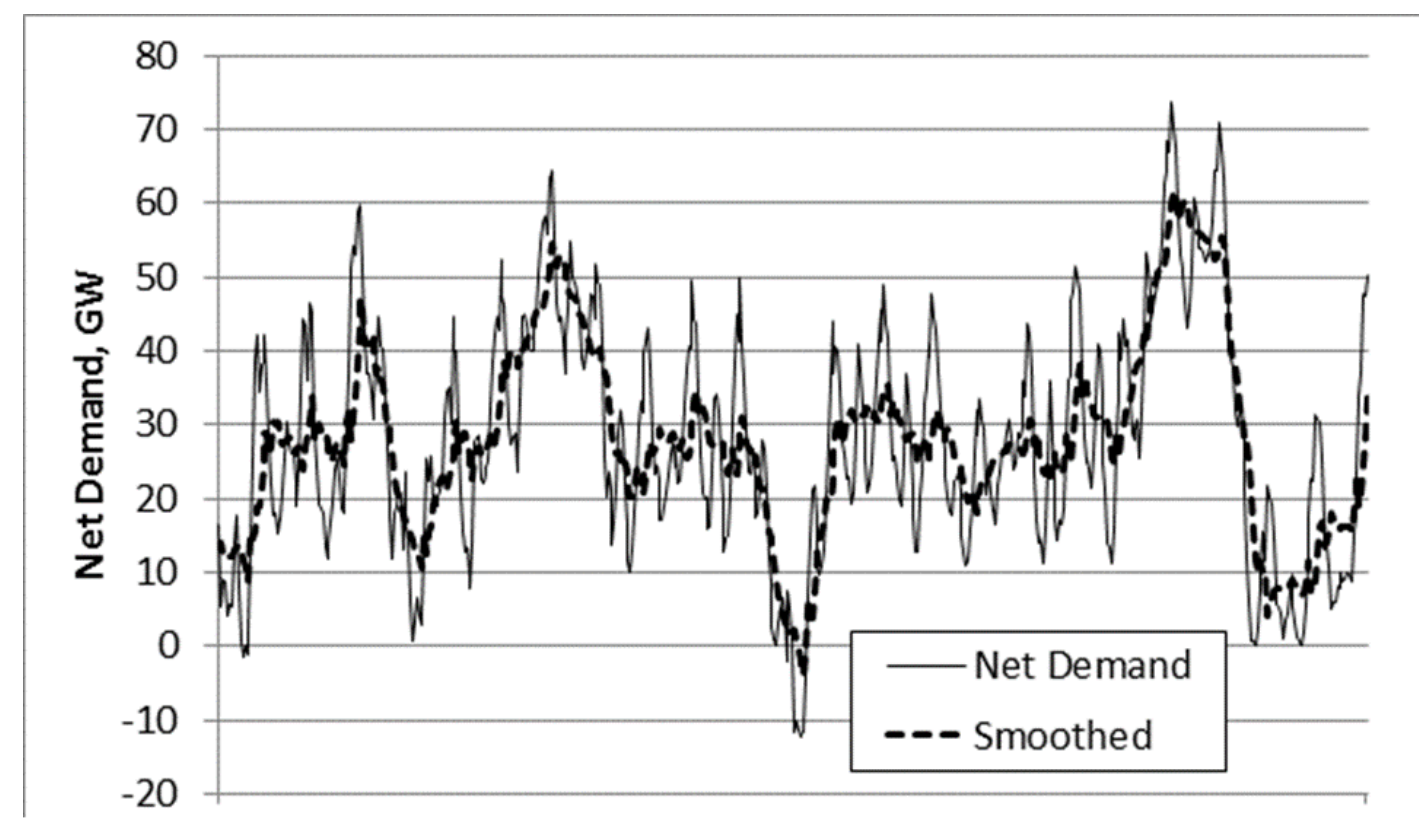

$232425262728 \quad 1 \quad 2 \quad 3 \quad 4 \quad 5 \quad 6 \quad 7 \quad 8 \quad 9 \quad 101112131415161718$

February

March

Figure 9. Higher Renewables pathway in $\mathbf{2 0 5 0}$ before and after application of storage and time-shifting of demand, 24 days in February and March

When this data is translated into load-duration curves, Figure 10, we also see a small reduction in the gradient of each curve and a small reduction in the range of net demand. However, the gradient and shape of the curves still depends very strongly on the pathway, and is still steeper than in 2010 indicating that energy storage and flexible demand have not solved the problem. 


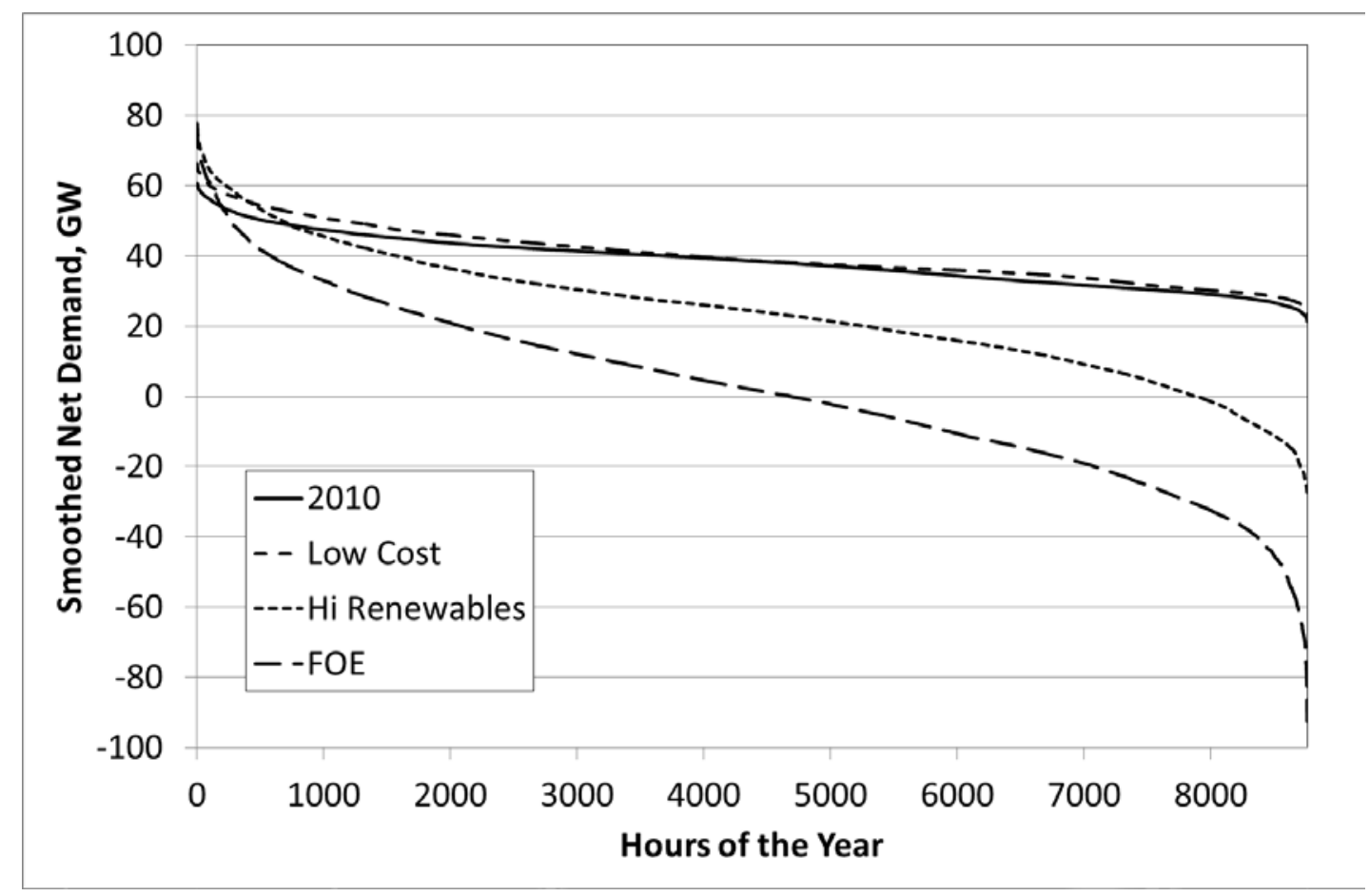

Figure 10. Net Demand Duration Curves for the UK in 2010 and under 3 lowcarbon scenarios in 2050, after energy storage and time-shifting of flexible demand

Furthermore, this analysis indicates the importance of long-term storage. Short-term variations in net demand can be smoothed out by today's pumped hydro energy storage and demand-shifting as modelled in FESA, but longer-term variations cannot. FESA shows that most variation in net demand falls into this second category, with peaks and troughs persisting for several days, Figure 9, or even up to 2 weeks, Figure 8.

\subsection{Unsatisfied Electricity Demand}

FESA shows that seven of the ten low-carbon DECC pathways suffer from some unsatisfied electricity demand by 2050 . The maximum unmet demand power level is fairly large, up to $16.2 \mathrm{GW}$ in the Atkins pathway, Figure 11, but the annual energy shortfall is modest, the largest being just 1.0TWh in the Higher CCS pathway. This means that the shortfall occurs for just a few hours on a few days of the year with the 
very highest peaks of net demand and might be accommodated by a little more flexible, time-shifted electricity demand and a little more flexible generation. The DECC 2050 Calculator uses a stress test of a 5-day period of low wind speeds and below-average temperatures (3). The DECC 2050 Calculator adds extra peak generating plant and some demand flexibility to aid grid balancing, but our modelling indicates that more is needed than was anticipated when the pathways were created. It is also apparent that, with the exception of Friends-Of-the-Earth, the pathways with the highest shortfall are also ones that do not include the highest level of flexibility in the form of energy storage, extra peak generation, international interconnectors and demand flexibility. Our modelling shows that when the DECC 2050 Calculator example pathways were created, the grid balancing challenge was under-estimated, especially the height of the worst winter peak of electricity demand, which in FESA were modelled using weather data from year 2001.

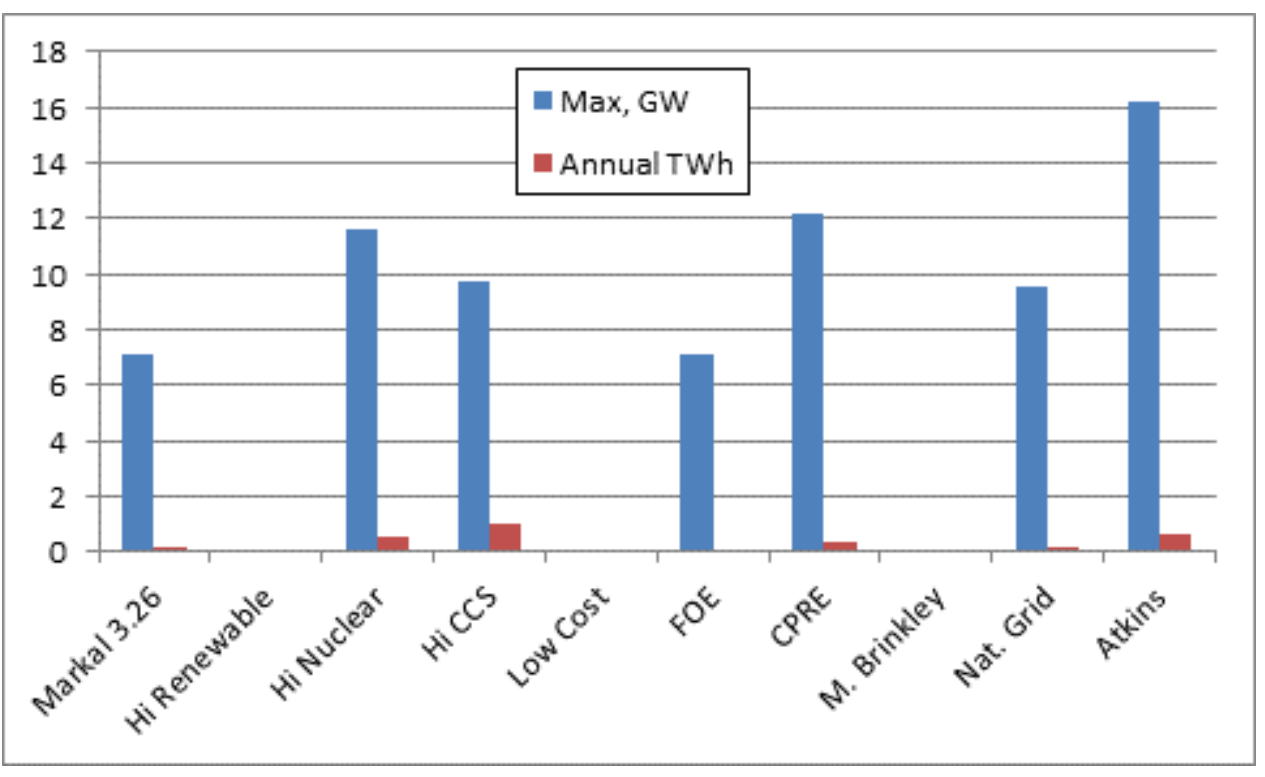

Figure 11. Unmet power as a maximum power shortfall and annual unmet energy demand for each pathway in 2050, as modelled by FESA 
On the one hand, extra flexibility should be quite feasible: It should be noted that the DECC 2050 Calculator specifies the flexibility of electric vehicle charging but does not include any flexibility in space heating or water heating. On the other hand, FESA already assumes that international interconnectors are fully accommodating to the needs of UK electricity systems. This may be an optimistic assumption given that the UK's European neighbours may experience similar shortfalls of electricity at the same time, and therefore be unable to export electricity to the UK. FESA may therefore underestimate the amount of unsatisfied electricity demand. The DECC 2050 Calculator assumes only 75\% availability of imported power which goes some way to modelling the limited availability of imported power, but then under-estimates the peaks of electricity demand.

It should also be noted that all these forms of demand response (electric vehicle charging, water heating and space heating) would do little to solve the lack of storage volume over longer multi-day periods, as raised elsewhere.

\subsection{Curtailed Excess Power}

FESA predicts that at other times of the year and under different weather conditions, most of the DECC pathways experience a surplus of electricity from the renewable and the less-flexible low-carbon generators when modelled in FESA. This surplus cannot all be used by energy storage, flexible demand or exported through international interconnectors, even assuming a market for that surplus in the UK's neighbouring markets. The DECC 2050 Calculator does include some calculation of ability to cope with winter-peak demand, but it does not consider surpluses, which vary greatly from one pathway to another. By year 2050 the maximum values and annual totals of curtailed (and therefore lost) electricity are shown in Figure 12.

These figures are a minimum, firstly because neighbouring countries may not always 
be able to accommodate surplus electricity from the UK and secondly because other transmission and operational constraints on the grid are ignored. For example, the electricity system of Ireland can only accommodate a certain percentage of nonsynchronous generation, which limits the penetration of wind power to $50 \%$ of system demand in the Irish electricity system (24-26).

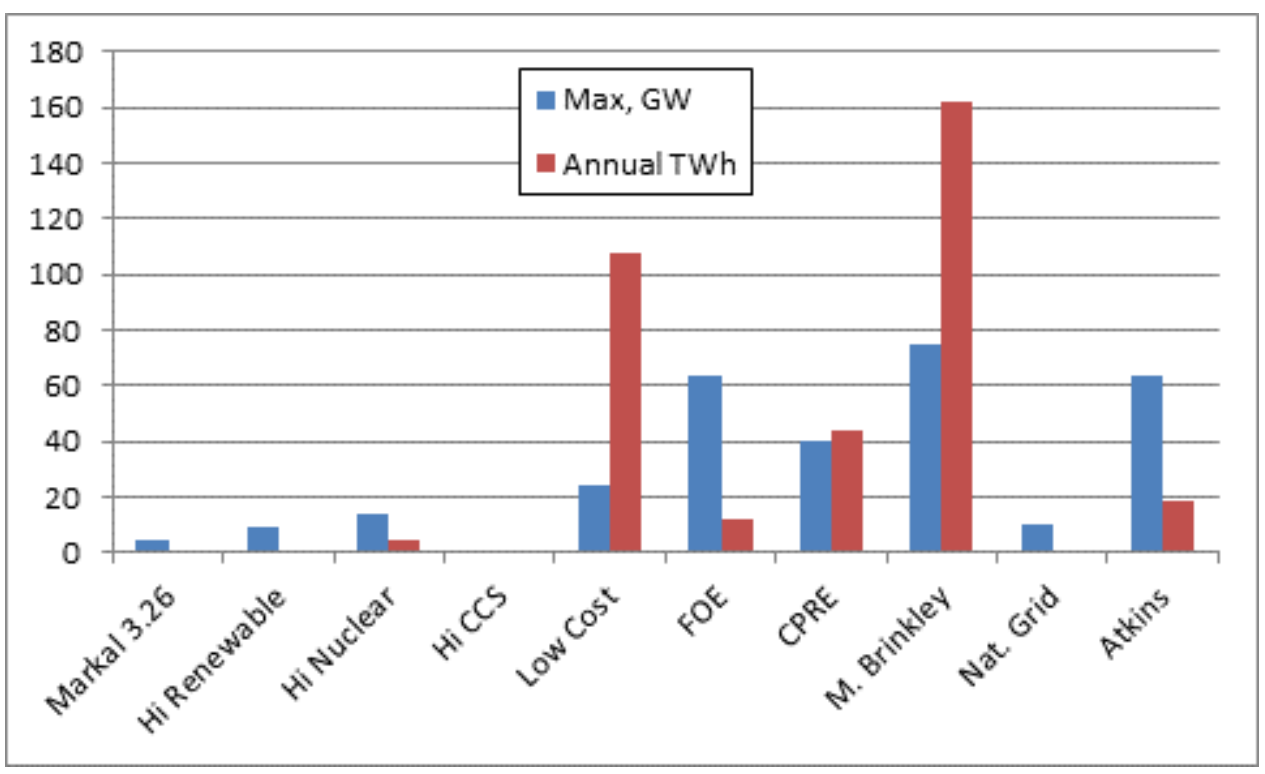

Figure 12. Curtailed surplus generation in each DECC pathway in year 2050, as a maximum power and as an annual total energy

It can be seen in Figure 12 that surpluses of electricity are generally much larger than the shortfalls of Figure 11 . To put these numbers into context, $60 \mathrm{GW}$ of surplus power (Friends-Of-the-Earth, Mark Brinkley and Atkins) is greater than the UK's winter peak electricity demand all being wasted, and 160TWh of energy (Mark Brinkley) is equal to half of a typical year's total electrical energy in 2010. These surpluses therefore represent a huge wasted resource if not used, stored or converted into a fuel. At the same time, in all pathways, the UK is a net importer of fuel in 2050, see Section 3.9. Longer term storage would reduce the amount of exported and curtailed energy in each pathway, while eliminating the unmet demand and reducing the need for installed capacity of despatchable generators and their 
fuel use. Investments in this longer term storage capacity are currently prevented by the high cost of long-term storage options and are outside the scope of this paper, but it is unlikely that it will ever be cost-effective to use energy storage to eliminate all curtailed energy. A cost-benefit analysis of longer term storage options is the subject of ongoing research using FESA modelling.

\subsection{Exported Electricity}

Because exported electricity has to accept whatever international markets will pay for it, the price is likely to be low. Arguably, this is a wasted resource given that the UK is a net importer of fuels under all the scenarios in year 2050, Section 3.9. All of the pathways export some electricity by 2050 , but the amount varies greatly from one pathway to another. The maximum exported power is usually limited by the power rating of international interconnectors but the total annual exported energy is largely determined by the hourly balance of supply and demand (FESA) or by the annual total balance (DECC 2050 Calculator). In most pathways, the exported energy in 2050 is much greater when modelled by the DECC 2050 Calculator than when modelled by FESA, Figure 13. This is a function of the despatch algorithms: The DECC 2050 Calculator merely assumes a constant, annual capacity factor for each type of generator, which results in a large over-supply of electricity from despatchable generators, regardless of the need for that electricity, see section 3.8. 


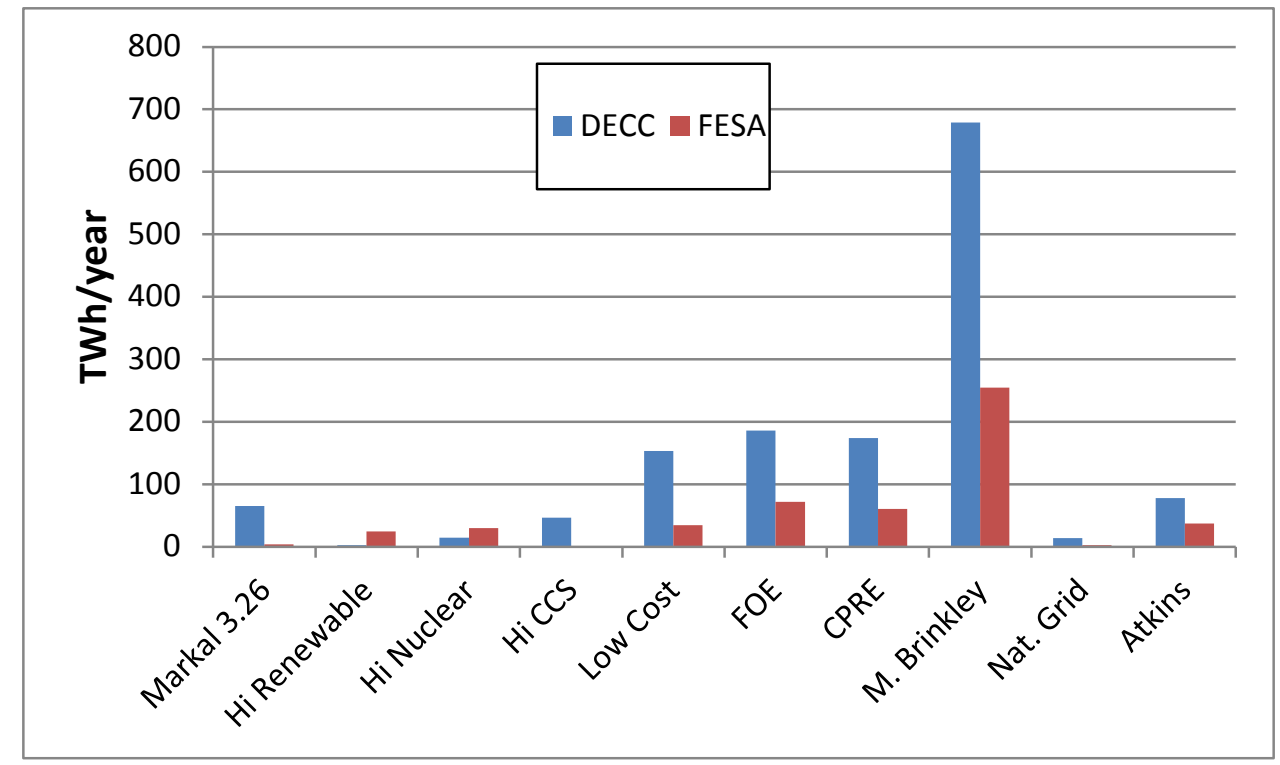

Figure 13. Annual exported electricity in 2050 predicted by the DECC 2050 Calculator and by FESA

Figure 13 shows that the amount of exported energy varies greatly from one pathway to another but when the amounts are large, the DECC 2050 Calculator's estimate is typically greater than FESA's by a factor of 2 or 3 , a consequence of the large assumed capacity factors of despatchable generators in the DECC 2050 Calculator.

In just two pathways (Higher Renewables and Higher Nuclear), FESA predicts more exported energy than DECC does, but still a small quantity. In these cases, electricity is exported on the few occasions when renewable and nuclear powered electricity exceed demand.

\subsection{Imported Electricity}

In the DECC 2050 Calculator, imported electricity is an input parameter to the model, and that is carried over into the FESA interpretation of the same pathways. However, when needed, FESA adds to imported electricity to meet occasional peaks of net demand. These periods of high demand and low renewable supply are rare and add 
just a small amount to the annual total imported electricity, Figure 14. As with exports, the annual maximum imported power is usually equal to the power capacity of the international interconnectors, but the imported power only reaches this limit in a few hours of the year. The power capacity limit makes only a small difference to the annual imported energy.

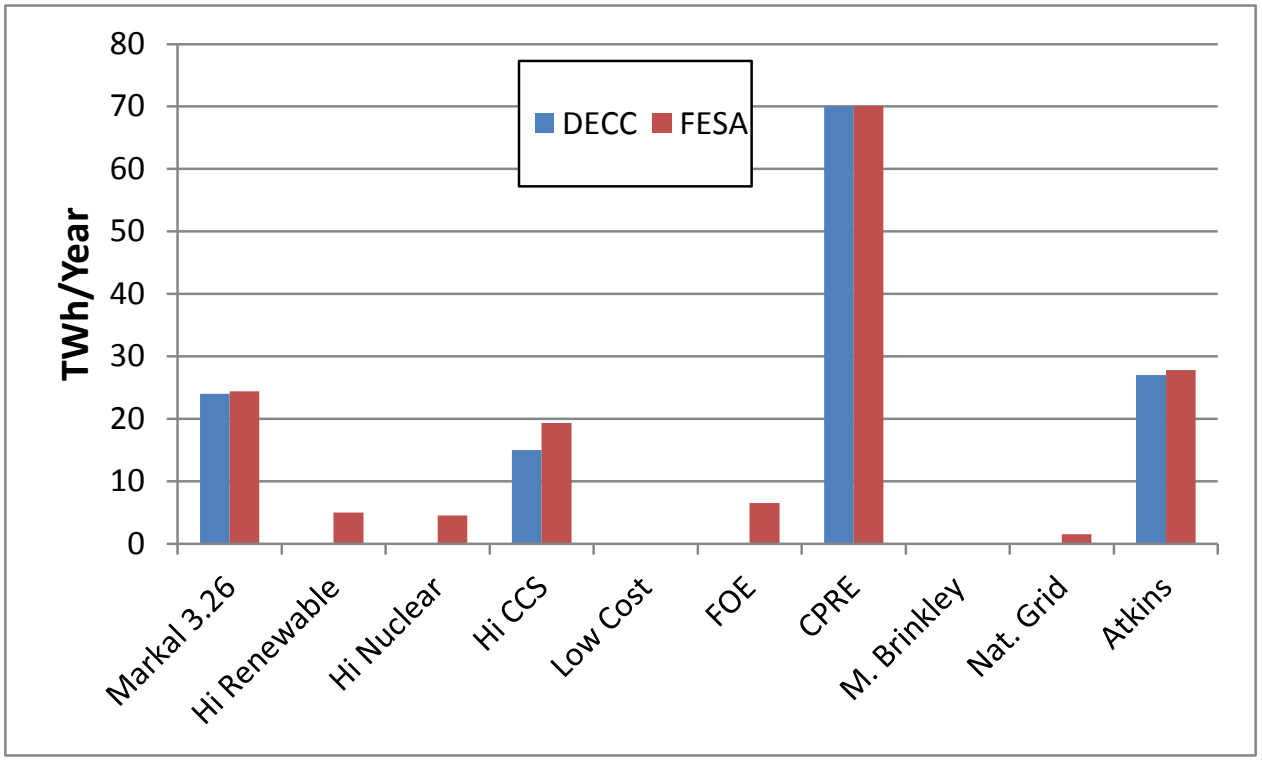

Figure 14. Annual imported electricity in 2050 predicted by the DECC 2050 Calculator and by FESA

Figure 14 shows that the imported electricity is dominated by the planned imports (4 of the pathways) but that FESA predicts a small increase in imports to accommodate periods of low supply and high demand (7 of the pathways). These extra imports for grid balancing, Figure 14, are an order of magnitude smaller than exported surpluses, Figure 13.

\subsection{Capacity Factors}

The capacity factors of despatchable (flexible) generation are a significant difference between the DECC 2050 Calculator and FESA, and are lower in FESA despite the use of smart demand shifting. In the DECC 2050 Calculator, all capacity factors are an input parameter but in FESA, the capacity factors of the despatchable generators 
are an output of the program, calculated by the grid balancing algorithm. FESA maintains the same capacity factors as DECC for the least flexible generators: nonthermal renewables, nuclear, hydro and geothermal generators. At the other end of the merit order, the open cycle gas turbines, oil-fired power stations and older, unabated coal and gas-fired power stations either operate at low capacity factor anyway by 2050 , or have small installed capacity. In the middle of the merit order in 2050 are coal and gas with CCS and biomass fuelled generators, which have assumed high capacity factor in the DECC 2050 Calculator but a much lower capacity factor in FESA by year 2050, Figure 15.

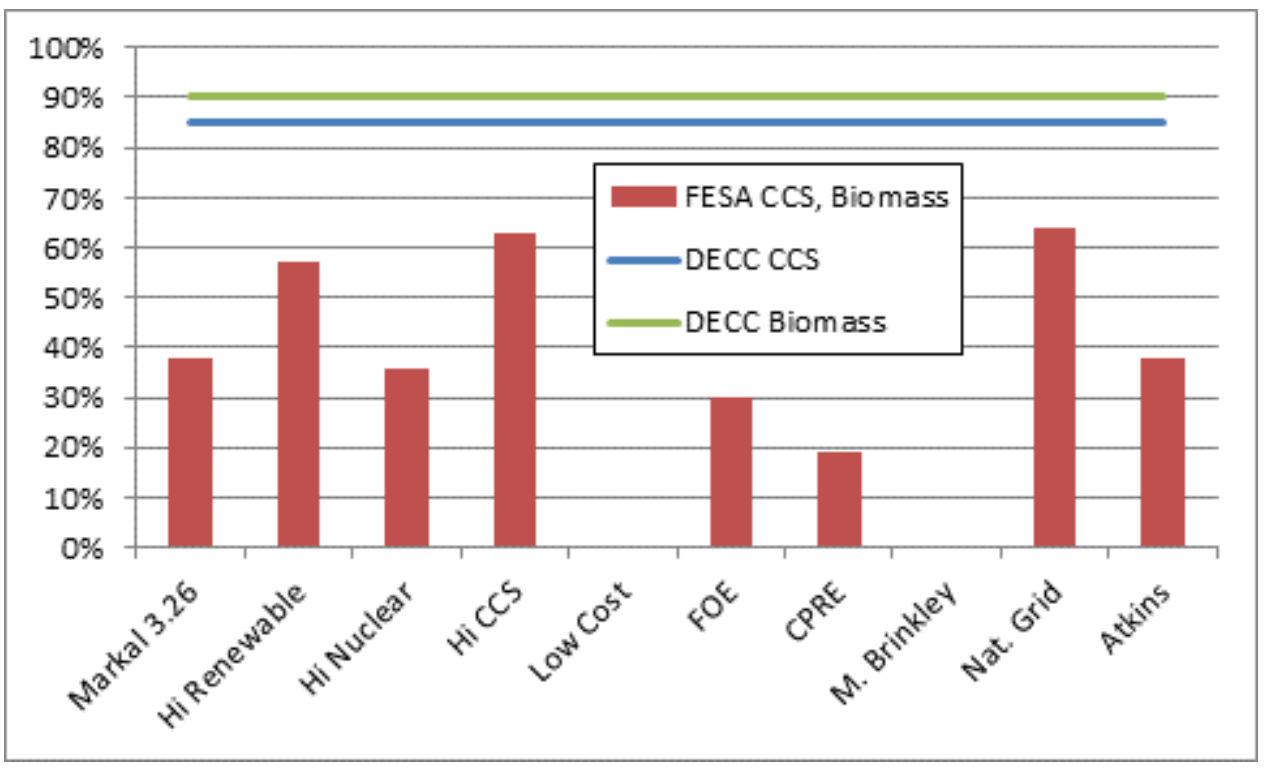

Figure 15. Generation capacity factors calculated by FESA, after smart demand-shifting, compared to those assumed by the DECC 2050 Calculator, in year 2050

Figure 15 shows that in all 10 pathways, the capacity factors of CCS and biomass plant calculated by FESA are substantially lower than those of the DECC 2050 Calculator, and in some cases zero or virtually zero. Note that the use of smart demand-shifting makes virtually no difference to the capacity factors of CCS in 
FESA, and fails to bring them close to the levels assumed in the DECC 2050 Calculator. Of equal importance is the rate at which these capacity factors decline, Figure 16, which is a function of the rate at which CCS generators are constructed, Figure 17 compared to the slow-down in electricity requirement from these plants, Figure 18. After an initial increase in capacity factor until 2030 when CCS technology becomes mature and more reliable (an effect copied across from the DECC 2050 Calculator) the capacity factors fall rapidly due to lack of electricity demand. The combined data of coal and gas CCS generators are shown for illustration, but all three generator types (gas with CCS, coal with CCS and biomass) have similar and converging capacity factors.

The capacity factors could be increased in FESA, or the amount of exported electricity in the DECC 2050 Calculator could be reduced, by reducing the installed capacity of CCS and biomass generators. However, that would reduce the electricity system's ability to meet peak net demands or jeopardise the $80 \%$ reduction in greenhouse gas emissions by 2050 . 


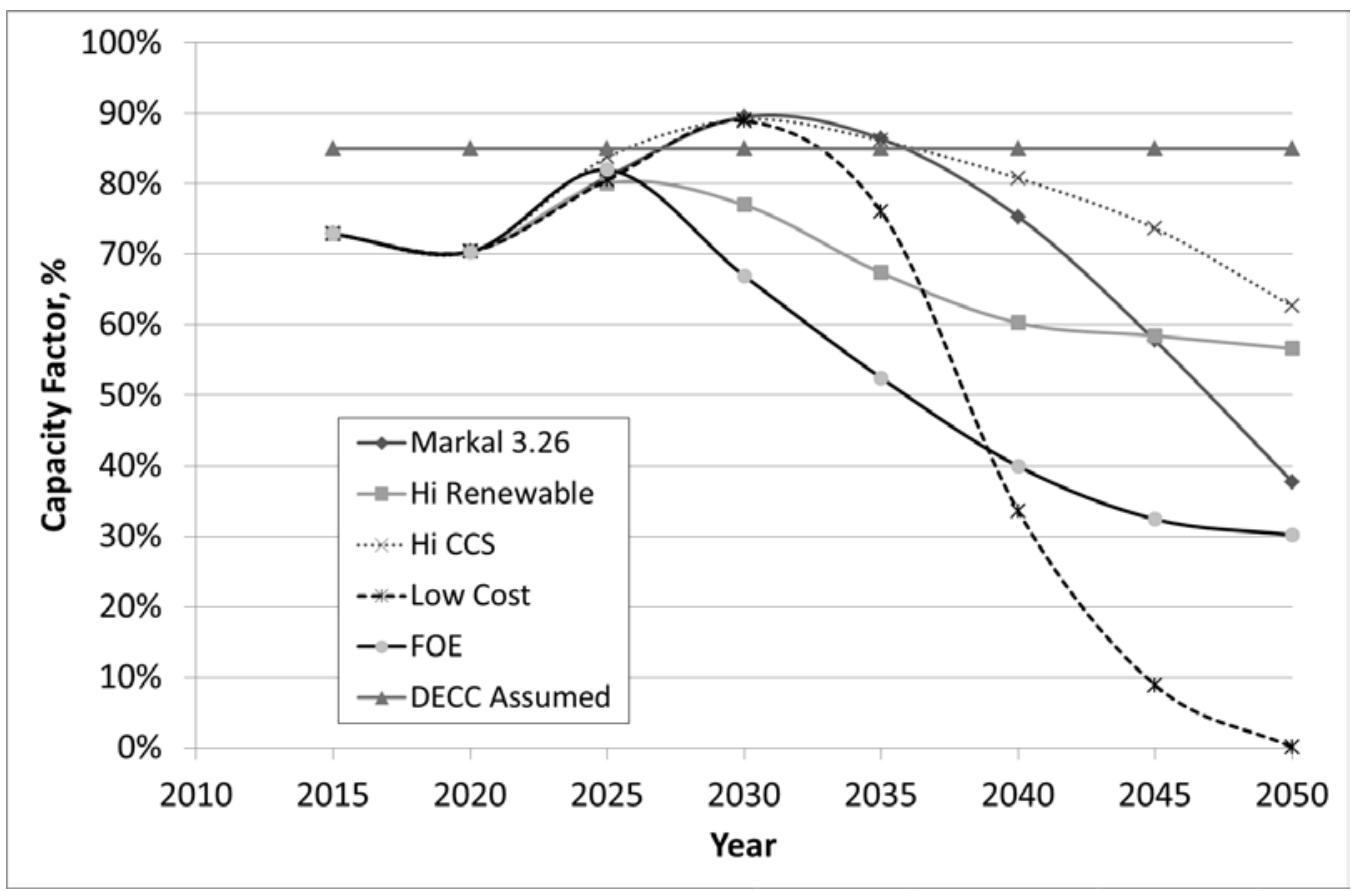

Figure 16. Combined capacity factors of CCS generators, years 2015 to 2050

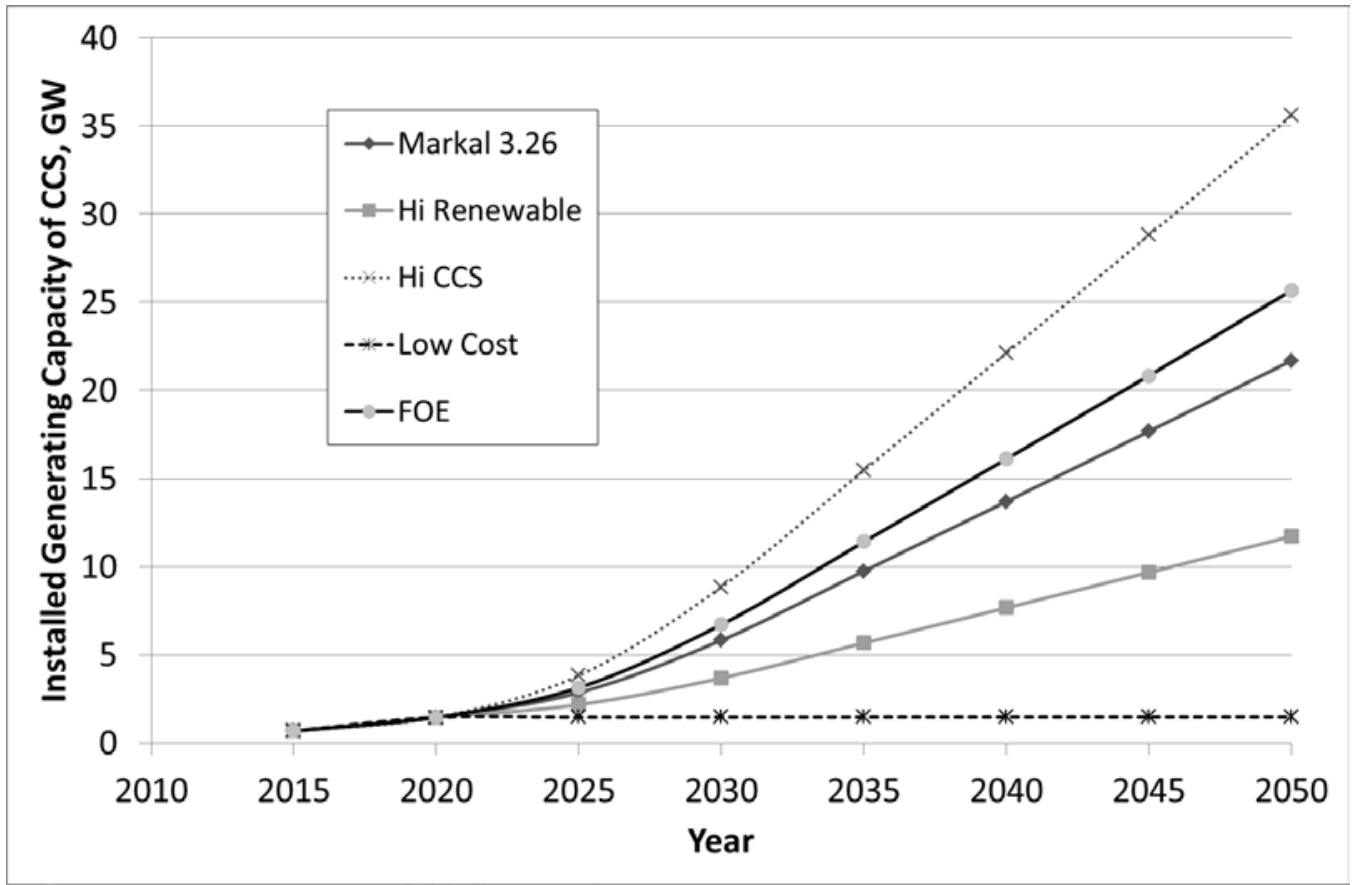

Figure 17.Total installed capacities of CCS generators, years 2015 to 2050 


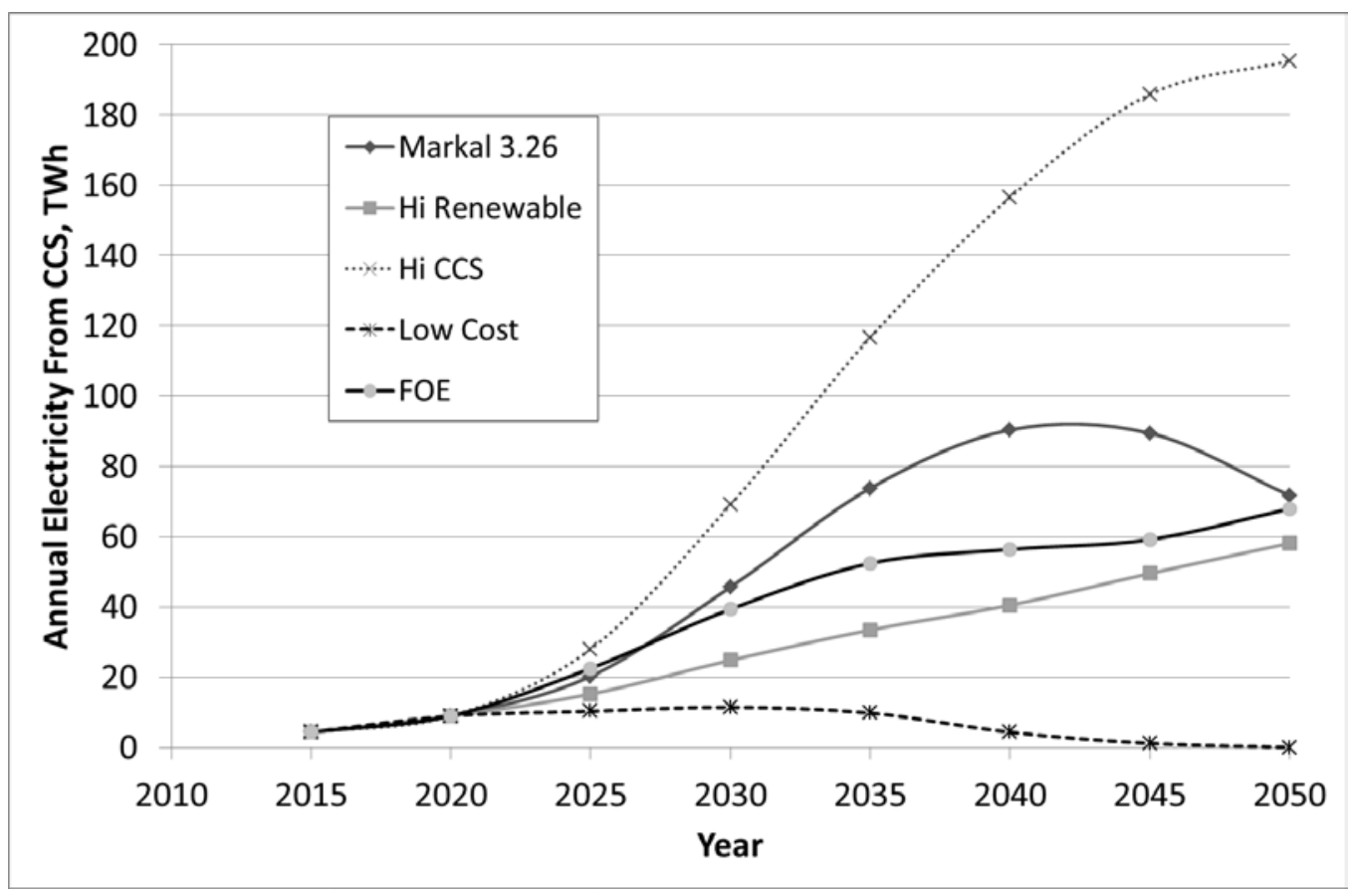

Figure 18. Total annual electricity from CCS generators, years 2015 to 2050

Figure 16, Figure 17 and Figure 18 show that low capacity factors of CCS generators are more serious in some pathways than others. The Higher CCS and National Grid pathways have high installed capacities of CCS, Figure 17 and high use, Figure 18, resulting in a high and maintained capacity factor, Figure 16 . At the other end of the scale, the Low Cost and Higher Nuclear pathways make very little use of CCS, but have very little installed capacity, resulting in relatively few stranded assets.

All the other six pathways have stagnating or declining output from CCS generators beyond 2035, continuing high installation rates and declining capacity factors, putting into question the financial viability of CCS (and biomass) generators constructed after 2030 in these pathways. The most unrealistic pathway appears to be Mark Brinkley, where 35GW of CCS plant is installed between 2010 and 2050, most of it after 2035, but virtually none of it is used after 2030 . 


\subsection{Imported Fuels}

Under all ten pathways in year 2050, the UK is a net importer of fuels. The picture with regard to some individual fuels (natural gas, coal, liquid biofuels and solid biomass) is a mixed one when modelled by FESA, Figure 19 but the total is always in the direction of imports to the UK. The UK always imports liquid crude oil and oil products but it always exports coal. In almost all cases, FESA predicts smaller imports of fuel (especially natural gas) and greater exports (coal) than when modelled by the DECC 2050 Calculator, Figure 20. This is because FESA recognises when electricity generation is not needed in the UK and reduces the capacity factor of despatchable generators, which in turn reduces fuel consumption.

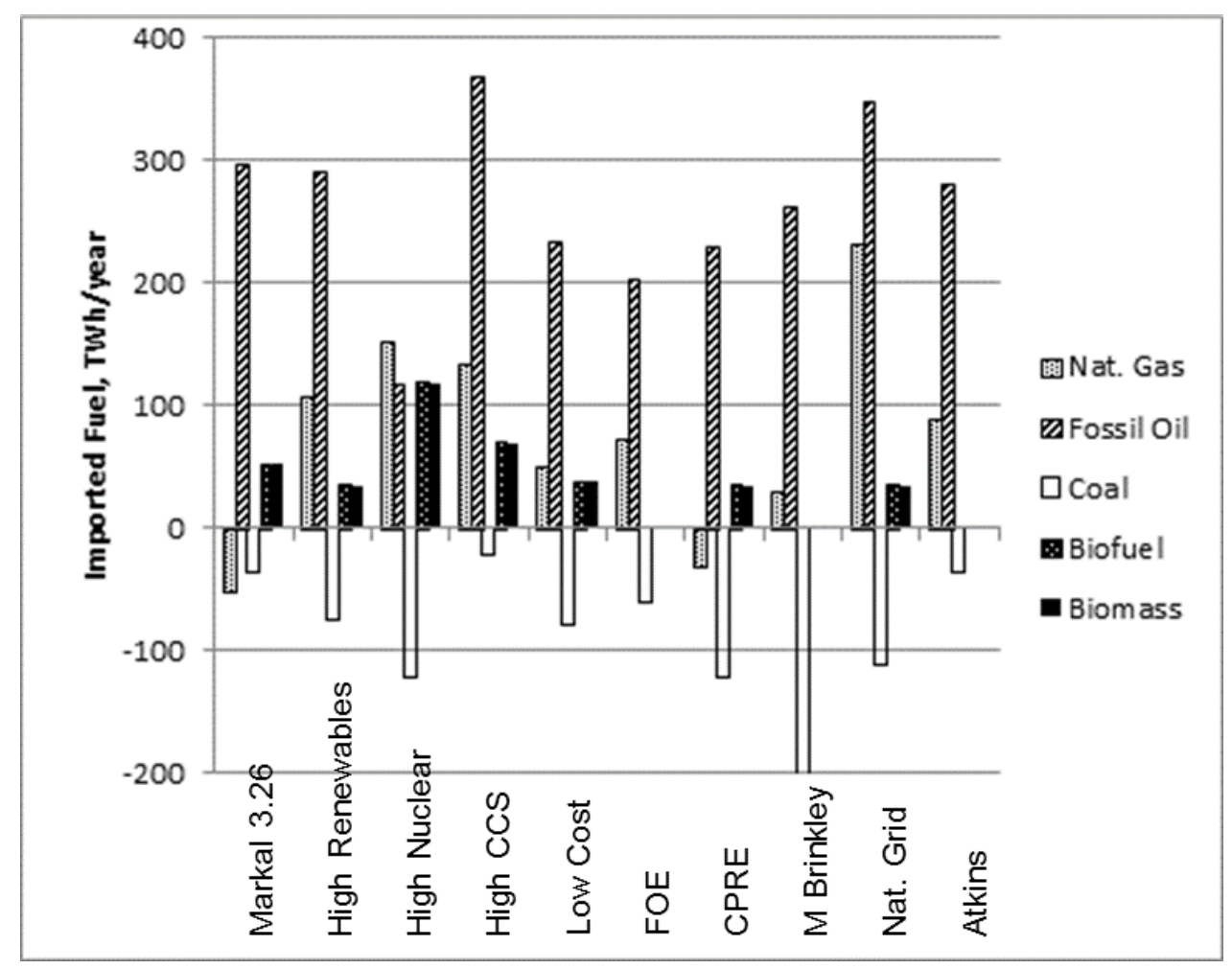

Figure 19.Annual imported fuels modelled by FESA in year 2050 


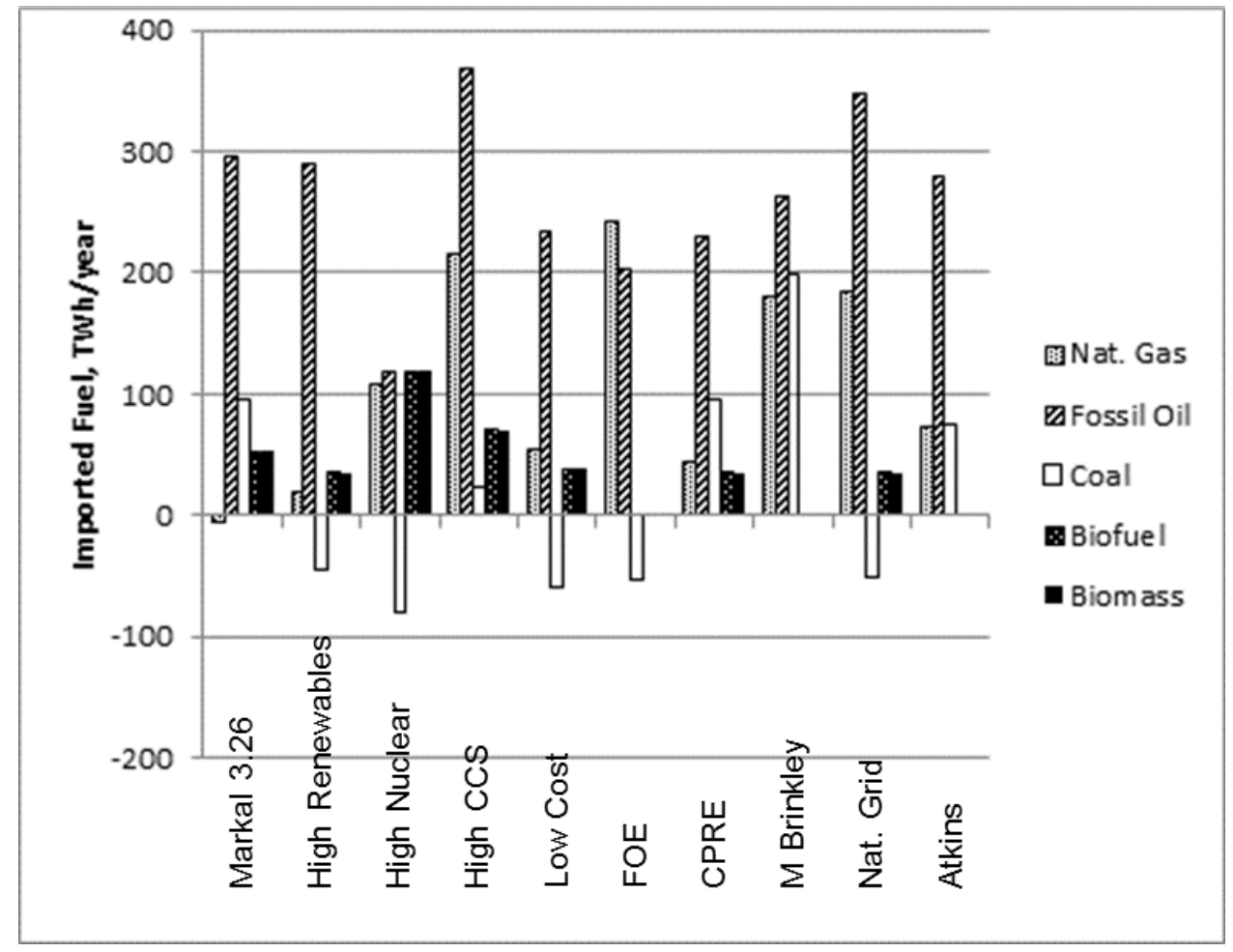

Figure 20. Annual imported fuels modelled by DECC 2050 Calculator in year 2050

Of all the pathways, the one created by Mark Brinkley has the smallest overall level of total imported fuel when modelled by FESA, Figure 19. This pathway may have been a deliberate attempt to create self-sufficiency in energy, but results in a very large surplus of electricity without eliminating imports of fuel.

Since the DECC pathways were created, hydraulic fracturing ('fracking') technology has substantially increased the extraction rate of natural gas and oil in the USA. If in the future, hydraulic fracturing also increases oil and gas production in the UK, then the UK may not become a net importer of fuels. Nevertheless, the UK would remain heavily dependent on fossil fuels. 


\subsection{Overall View of the Merits of the Pathways}

Combining and comparing the above results, it is possible to see which pathways do best overall in balancing supply and demand of electricity while making good use of generation assets, Table 2. The peak and annual total values of unmet demand are self-explanatory, while the annual curtailed energy and annual exported energy were explained above in Sections 3.5 and 3.6. The 'stranded CCS capacity' is the total generating capacity of CCS installed, subtracting the generating capacity that would give the same amount of annual electricity if operated at $85 \%$ capacity factor, as assumed in the DECC 2050 Calculator.

\begin{tabular}{|c|c|c|c|c|c|}
\hline $\begin{array}{l}\text { Pathway in } \\
\text { Year } 2050\end{array}$ & $\begin{array}{l}\text { Peak } \\
\text { Unmet } \\
\text { Demand, } \\
\text { GW }\end{array}$ & $\begin{array}{l}\text { Annual } \\
\text { Unmet } \\
\text { Demand, } \\
\text { TWh/y }\end{array}$ & $\begin{array}{l}\text { Curtailed } \\
\text { Energy, } \\
\text { TWh/y }\end{array}$ & $\begin{array}{l}\text { Exported } \\
\text { Energy, } \\
\text { TWh/y }\end{array}$ & $\begin{array}{l}\text { Stranded CCS } \\
\text { Capacity, 10GW }\end{array}$ \\
\hline Markal 3.26 & 7.1 & 0.2 & 0 & 3.8 & 12.1 \\
\hline $\begin{array}{l}\text { Higher } \\
\text { Renewables }\end{array}$ & 0 & 0 & 0.3 & 24.7 & 3.9 \\
\hline Hi Nuclear & 11.6 & 0.5 & 4.6 & 29.5 & 0.9 \\
\hline Hi CCS & 9.7 & 1 & 0 & 0.01 & 9.4 \\
\hline Low Cost & 0 & 0 & 107.7 & 34.7 & 1.5 \\
\hline
\end{tabular}




\begin{tabular}{|l|l|l|l|l|l|}
\hline FOE & 7.1 & 0.03 & 11.7 & $\mathbf{7 2}$ & $\mathbf{1 6 . 6}$ \\
\hline CPRE & $\mathbf{1 2 . 2}$ & $\mathbf{0 . 3}$ & $\mathbf{4 3 . 8}$ & $\mathbf{6 0 . 8}$ & $\mathbf{1 9 . 4}$ \\
\hline M. Brinkley & 0 & 0 & $\mathbf{1 6 2 . 3}$ & $\mathbf{2 5 4 . 9}$ & $\mathbf{3 5 . 2}$ \\
\hline Nat. Grid & $\mathbf{9 . 5}$ & 0.2 & 0.2 & 2.3 & 6.2 \\
\hline Atkins & $\mathbf{1 6 . 2}$ & $\mathbf{0 . 6}$ & 18.9 & 37.3 & 10.2 \\
\hline $\begin{array}{l}\text { Arithmetic } \\
\text { Average } \\
\text { Values }\end{array}$ & 7.3 & 0.28 & 35 & 52 & 11.5 \\
\hline
\end{tabular}

Table 2. Pathway performance parameters as calculated using FESA in year 2050

Thresholds have been chosen as shown in the last line of Table 2, indicating whether a pathway is better or worse than average in each category, also indicated by numbers in bold and italics for numbers that are larger and therefore worse. We can see that the Markal 3.26, Higher Renewables, Low Cost and National Grid scenarios in 2050 perform well in all or all but one of the categories, while the Campaign to Protect Rural England and Mark Brinkley perform poorly in at least three categories. Note that if the additional, fuel-saving uses of excess electricity were included as described in section 3.12 then the picture might look much better for these scenarios with large amounts of exported or curtailed energy. 


\subsection{Limitations of the Models}

FESA is a single-node model: it assumes unconstrained power flows throughout the UK. Spatial disaggregation of intermittent renewables may reveal point stresses on parts of the system, but it should be noted that the intermittent renewables are distributed around the UK in useful way: solar PV is predominantly in the South of the UK, close to centres of demand; Onshore wind is located mainly in the North and West of the UK but is balanced to some extent by Offshore wind located in shallow seas around the South and East of the UK.

It includes international interconnectors but the grid balancing problem within the countries at the other end of each connector is outside the scope of the model. The use of international interconnectors might therefore be seen as unrealistically favourable to the UK: Weather patterns can span several countries, especially highpressure weather systems and might cause a simultaneous drop in wind power output. Why would the UK's neighbours accommodate the needs of the UK when they might also experience similar grid balancing problems at the same time? These simplifications are shared with the DECC 2050 Calculator and are further reasons that both models under-estimate the grid balancing problem. In the worst-case, if the UK is unable to import power at times of peak net demand, the peak unmet demand, Table 2, could be increased by the power rating of the interconnector, ranging from 4GW in the case of the Low-cost pathway to an additional 30GW in the Higher Renewables, FOE and M. Brinkley pathways. In justification of this model of interconnectors, continental Europe is geographically larger and more fully integrated between different countries, and therefore more able to aggregate electricity supply and demand over a larger area. 
FESA also under-estimates the grid balancing challenge because it only uses one year of weather data and demand data. Year-to-year variability means that in some years the unmet demand or curtailed power will be much worse. In the real UK electricity systems of 2016, more margin is built into the despatchable generating capacity. Analysis of inter-annual variation in renewable energy generation, for example wind resource (27) indicates that over a 30-year period the weather-related annual average capacity factor of onshore wind power can vary between $24 \%$ and $36 \%$. If the amount of installed wind power were sized for the worst year, then the best year might result in an over-supply of 50\% which would be curtailed. Conversely, if wind power is sized for an average year, then a worst year will leave a $20 \%$ shortfall in wind power and a greater risk of unmet demand.

\subsection{The Need for More Flexibility and Energy Storage}

The DECC 2050 Calculator is limited because it fails to pursue ways of reducing the surplus of electricity, sections 3.5 and 3.6 , by using it to save or make fuels. There are many potential technologies to do this: electric water heating with hot water storage (28-30), electric space heating, electrification of industrial and agricultural processes, flexible use of plug-in electric vehicles (PHEVs) (31). In this context, the electrification of water heating, space heating, industrial and agricultural processes, and vehicles means the use of additional, secondary systems such that electricity is used when available, but fuels are used when electricity is not available. Flexibility also includes the greater deployment of grid-connected bulk energy storage, flexible hydrogen production by electrolysis of water (power-to-gas) $(32,33)$, and production of synthetic fuels (34) 
Inputs to FESA were set up to be as faithful as possible to the DECC 2050 Calculator, and in so doing, neither the DECC 2050 Calculator nor FESA include these energy transformations. If they were included, the electricity surpluses of sections 3.5 and 3.6 would be reduced, as would the fuel imports of section 3.9.

\section{Conclusions}

The FESA model has been used to perform an hourly time-step analysis of the ten low-carbon example pathways of the DECC 2050 Calculator version 3.4.6 using the same assumptions as far as possible, and taking as many inputs as possible directly and automatically from the Excel version of the DECC 2050 Calculator. This analysis reveals the following.

- The grid balancing challenge is much greater than is suggested by the DECC 2050 Calculator.

- Most of the example pathways fail to meet the peaks of net electricity demand, even with smart grid technologies, flexible demand and flexible imports. In most cases, the unmet demand is a modest shortfall of power, up

to $16 \mathrm{GW}$ peak, and a very small shortfall in annual energy, not more than 1 TWh/year and persisting for only a few hours.

- The DECC 2050 Calculator's assumptions of large installed generating capacities, together with high capacity factors for despatchable generators, result in very large surpluses of electricity not required in the UK. The Calculator makes a poor assessment of these surpluses. In most cases, it predicts a large excess of electricity that is exported, but fails to calculate how much is in excess of what can be exported. FESA calculates that a large 
amount of energy is curtailed, with up to 75 GW peak and 160 TWh/year completely lost. These surpluses can persist for many days and indicate the importance of developing long-term energy storage technologies (days and weeks, not just hours) including power-to-gas or other fuel-producing technologies.

- When analysed in FESA, all the example pathways result in a lower capacity factor for CCS and biomass generators than indicated in the DECC 2050 Calculator. In several of the pathways this results in many GW of generating capacity operating for only a few hours of the year, only a few years after it is constructed. Demand shifting makes little improvement. It is therefore doubtful that all these generators, especially some of those with CCS, can be financially viable under those DECC pathways.

- Both DECC 2050 Calculator and FESA predict that in most of the pathways, the UK will be a large net importer of fuels, or a large net exporter of electricity, or both by year 2050 .

- Short-term time-shifting forms of demand response have very limited benefit to grid balancing but fuel-switching technologies show promise in helping to address many of the above problems, by flexibly using electricity instead of a fuel. Fuel switching technologies currently omitted from the models include flexible heating systems, flexible operation of plug-in hybrid vehicles and power-to-gas. 


\section{Acknowledgement}

This work was supported by the Engineering and Physical Sciences Research Council, UK, within projects: Realising Transition Pathways - Whole Systems Analysis for a UK More Electric Low Carbon Energy Future EP/K005316/1 and Integrated, Market-fit and Affordable Grid-scale Energy Storage (IMAGES) $\mathrm{EP} / \mathrm{K} 002228 / 1$ 


\section{References}

1. Climate Change Act Chapter 27, UK Government. 2008 [cited 2014]. Available from: http://www.legislation.gov.uk/ukpga/2008/27/contents;

2. Carbon Plan, UK Government. 2011 [cited 2014]. Available from: https://www.gov.uk/government/publications/the-carbon-plan-reducinggreenhouse-gas-emissions--2;

3. 2050 Pathways Analysis, UK Department of Energy and Climate Change (DECC). 2010 [cited 2014]. Available from:

https://www.gov.uk/government/uploads/system/uploads/attachment data/file/ 68816/216-2050-pathways-analysis-report.pdf;

4. Foxon $\mathrm{T}$, Hammond $\mathrm{G}$ and Pearson $\mathrm{P}$. Developing transition pathways for a low carbon electricity system in the UK. Technol. Forecasting Social Change 2010; 77(8): 1203-1213. DOI:10.1016/j.techfore.2010.04.002

5. Trutnevyte E, Barton J, O'Grady A et al. Linking a storyline with multiple models: A cross-scale study of the UK power system transition. Technol. Forecasting Social Change 2014; 89: 26-42.

DOI:10.1016/j.techfore.2014.08.018

6. Barnacle M, Robertson E, Galloway S et al. Modelling generation and infrastructure requirements for transition pathways. Energ. Policy 2013 1; 52: 60-75. DOI:10.1016/j.enpol.2012.04.031 
7. Barton J, Huang S, Infield D et al. The evolution of electricity demand and the role for demand side participation, in buildings and transport. Energ. Policy 2013; 52: 85-102. DOI:10.1016/j.enpol.2012.08.040

8. Lannon S, Georgakaki A,Macdonald S. Modelling urban scale retrofit, pathways to 2050 low carbon residential building stock. In: 13th Conference of International Building Performance Simulation Association, Chambery, France, 26-28 August 2013.

9. Barton $\mathrm{J}$ and Gammon R. The production of hydrogen fuel from renewable sources and its role in grid operations. J. Power Sources 2010; 195(24): 8222-8235. DOI:10.1016/j.jpowsour.2009.12.100

10. DECC. History of published versions of the 2050 Calculator, http://2050calculator-tool-wiki.decc.gov.uk/pages/140. (2014, Accessed 16th July 2015).

11. National Environmental Research Council (NERC), British Atmospheric Data Centre. 2004, http://badc.nerc.ac.uk/home/. (2004, Accessed 3rd December 2004).

12. National Grid. Metered half-hourly electricity demands, http://www.nationalgrid.com/uk/Electricity/Data/Demand+Data/ (2001, Accessed 2005).

13. DECC. The future of heating: Meeting the challenge, Evidence annex. Report, https://www.gov.uk/government/uploads/system/uploads/attachment_data/file/ 190151/16_04_DECC-The_Future_of_Heating-

Evidence_Annex_ACCESSIBLE.pdf (2013, Accessed 2015).

14. Acha S, Green T, Shah N. Optimal charging strategies of electric vehicles in the UK power market. In: IEEE PES Innovative Smart Grid Technologies Conference, Hilton Anaheim, CA, USA; 17th to 19th January 2011, 
http://ieeexplore.ieee.org/stamp/stamp.jsp?tp=\&arnumber=5759128 and https://workspace.imperial.ac.uk/urbanenergysystems/Public/Acha_ISGT_201 1.pdf (2011, Accessed 2015).

15. Huang S and Infield DG. The potential of domestic electric vehicles to contribute to power system operation through vehicle to grid technology. In: Proceedings of the 44th International Universities Power Engineering Conference, University of Strathclyde, Glasgow; 1st to 4th September 2009, https://www.upec2009.org/content/node/285 (2009, Accessed 2015).

16. Committee on Climate Change. Energy prices and bills - impacts of meeting carbon budgets. Report, December 2014.

http://www.theccc.org.uk/publication/energy-prices-and-bills-impacts-ofmeeting-carbon-budgets-2014l; (Accessed 2015).

17. Ofgem - Smart Metering Team. Smart Metering - Functional Requirements Catalogue. Report no. URN:11D/680, 30 ${ }^{\text {th }}$ March 2011, http://www.ofgem.gov.uk/eserve/sm/Documentation/Documents1/Functional\%20Requirements\%20Catal ogue.pdf (Accessed 19th September 2011).

18. Ofgem - Smart Metering Team. Smart metering implementation programme: statement of design requirements. Report no. 94b/10, 27th July 2010 http://www.ofgem.gov.uk/eserve/sm/Documentation/Documents1/Smart\%20metering\%20\%20Statement\%20of\%20Design\%20Requirements.pdf (Accessed 5th September 2011). 
19. Energy Efficiency News. UK to roll out smart meters to all households by 2020, http://www.energyefficiencynews.com/i/1532/; (30th October 2008, Accessed 5th September 2011).

20. Towards a smarter future: Government response to the consultation on electricity and gas smart metering, DECC, http://www.decc.gov.uk/en/content/cms/consultations/smart metering/smart metering.aspx; (December 2009, Accessed 2011).

21. MacKay DJC. Sustainable Energy - without the hot air. Cambridge, UK: UIT Cambridge Ltd; 2008.

22. Day G, Foote P, McCloy D, et al. Scotland Wind Power and Pumped Hydro Potential. Available at: http://www.esru.strath.ac.uk/EandEMeb sites/0304/wind/content/storage\%20available.html; (2009, Accessed $26^{\text {th }}$ October 2016).

23. McKenna EJ and Thomson M. Impact of wind curtailment and storage on the Irish power system 2020 renewable electricity targets: A free open-source electricity system balancing and market (ESBM) model. In 3rd Renewable Power Generation Conference (RPG 2014), 24-25 September 2014, pp.1-6. http://ieeexplore.ieee.org/xpls/abs all.jsp?arnumber=6993238\&tag=1; DOI:10.1049/cp.2014.0845

24. Eirgrid and SONI. 2012 Curtailment Report, 2013. http://www.soni.Itd.uk/media/documents/operations/renewables/2012 curtailm ent report.pdf; (2013, Accessed 11th February 2016).

25. Mc Garrigle EV, Deane JP and Leahy PG. How much wind energy will be curtailed on the 2020 Irish power system? Renew. Energ. 2013; 55: 544-553. 
26. McKenna E, Grünewald P and Thomson M. Going with the wind: temporal characteristics of potential wind curtailment in Ireland in 2020 and opportunities for demand response. IET Renewable Power Gener. 2015; 9: 66-77.

27. Sinden G. Characteristics of the UK wind resource: long-term patterns and relationship to electricity demand. Energ. Policy 2007; 35(1):112-127. doi:10.1016/j.enpol.2005.10.003

28.4eco Limited. Immersun. https://www.immersun.co.uk/ (Accessed 15th April 2016).

29. Cool Power Products. Cool Power Products, Smart Sustainable Energy. http://coolpowerproducts.com/home. (Accessed 15th April 2016).

30. Parra D, Walker GS and Gillott M. Are batteries the optimum PV-coupled energy storage for dwellings? Techno-economic comparison with hot water tanks in the UK. Energy Build. 2016; 116: 614-621.

DOI:10.1016/j.enbuild.2016.01.039

31. Andersson S, Elofsson AK, Galus MD et al. Plug-in hybrid electric vehicles as regulating power providers: Case studies of Sweden and Germany. Energ. Policy 2010; 38 (6): 2751-2762. DOI:10.1016/j.enpol.2010.01.006

32. Hydrogenics. Power-To-Gas: Bridging the Power Grid and Natural Gas System, http://www.hydrogenics.com/hydrogen-products-solutions/energystorage-fueling-solutions/power-to-gas. (2013, Accessed 15th April 2016).

33. ITM Power. Power-To-Gas Energy Storage, http://www.itmpower.com/sectors/power-to-gas-energy-storage. (2016, Accessed 15th April 2016). 
34. Palmer E. Audi creates green 'e-diesel fuel of the future' using just carbon dioxide and water. International Business Times, 27th April 2015.

35. UK Met Office. Marine Automatic Weather Station (MAWS) Network. 2016; Available at: http://www.metoffice.gov.uk/public/weather/marineobservations/\#?tab=marineObsMap\&marineLocld=162091 $\left(\right.$ Accessed $1^{\text {st }}$ August 2005).

36. UK Met Office. Hadley Centre Central England Temperature (HadCET) dataset; Available at: http://hadobs.metoffice.com/hadcet/. (Accessed 2009)

37. Day T. Degree-days: theory and application. 2006 September 2006; Report no. TM41, September 2006. London: The Chartered Institution of Building Services Engineers (CIBSE).

http://www.degreedaysforfree.co.uk/pdf/TM41.pdf (Accessed $20^{\text {th }}$ October 2016)

38. Dolman M, Walker I, Wright A, et al. Demand side response in the nondomestic sector. Final report for Ofgem, July 2012. http://www.elementenergy.co.uk/wordpress/wp-content/uploads/2012/07/Demand-SideResponse-in-the-non-domestic-sector.pdf (Accessed 20 ${ }^{\text {th }}$ October 2016) 39. DECC. Energy consumption in the United Kingdom (ECUK). Report no. URN: 13D/165, 2013. London: DECC, BEIS.

https://www.gov.uk/government/collections/energy-consumption-in-the$\underline{\text { uk\#documents }}$ (Accessed $20^{\text {th }}$ October 2016)

40. Elexon Ltd. Electricity user load profiles by profile class. 1997. UKERC. http://data.ukedc.rl.ac.uk/browse/edc/Electricity/LoadProfile/data (Accessed 1st September 2011). 
41. Woods P, Dickson J. The contribution CHP can make to energy efficiency in buildings. In: Energy Efficiency in Buildings IMechE Seminar, (Parsons Brinckerhoff Ltd - Energy Services Division and Combined Heat and Power Association), 23rd March 2004.

http://www.chpa.co.uk/news/news downloads/2005/040221-

IMechE\%20paper\%20-\%20paul\%20woods-final.pdf (Accessed $1^{\text {st }}$ October 2009).

42. Knight I, Kreutzer N, Manning M, et al. European and Canadian non-HVAC electric and DHW load profiles for use in simulating the performance of residential cogeneration systems. Report no. M154-12/2007E:1-72, May 2007. Series: Annex 42 of the International Energy Agency. http://cogensim.net/index.php?pg=\&download=Annex 42 Subtask A Final Report on Domestic Energy Profiles.pdf (Accessed $1^{\text {st }}$ October 2009)

43. Hesmondhalgh, S. What can demand modelling tell you about electricity demand in the near future? In: GB electricity demand - realising the resource. Workshop report, Royal Society, 6-9 Carlton House Terrace, London, 16th May 2013. Brattle Group. http://www.sustainabilityfirst.org.uk/images/publications/gbelec/UKERC\%20\%20GB\%20Electricity\%20Demand\%20Workshop\%20-

\%20UKERC\%20Report\%20-\%2016\%20May\%202013.pdf (Accessed 20 ${ }^{\text {th }}$ October 2016). 


\section{Appendix: Description of Input Data Used by FESA}

\section{A1. Table of Annual Time Series Data Used in FESA}

The following inputs to FESA use one year of data as hourly averages.

\begin{tabular}{|c|c|c|}
\hline Name & \multirow{2}{*}{\multicolumn{2}{|c|}{$\begin{array}{l}\text { Description and Origin of Data } \\
\text { National Grid data (12) from year } 2001 \text { measured as half-hour } \\
\text { averages and aggregated to hourly averages. }\end{array}$}} \\
\hline $\begin{array}{l}\text { Total electricity } \\
\text { demand }\end{array}$ & & \\
\hline $\begin{array}{l}\text { Offshore wind } \\
\text { power }\end{array}$ & \multicolumn{2}{|c|}{$\begin{array}{l}\text { Wind speed data (11) from many coastal sites in } 2001 \text { as } \\
\text { proxy for offshore, extrapolated to typical offshore hub height } \\
\text { and put through a typical turbine power curve }\end{array}$} \\
\hline $\begin{array}{l}\text { Onshore wind } \\
\text { power }\end{array}$ & \multicolumn{2}{|c|}{$\begin{array}{l}\text { Wind speed data (11) from many sites in } 2001 \text {, extrapolated to } \\
\text { typical onshore hub height and put through a typical turbine } \\
\text { power curve }\end{array}$} \\
\hline $\begin{array}{l}\text { Normalised solar } \\
\text { power }\end{array}$ & \multicolumn{2}{|c|}{$\begin{array}{l}\text { Solar global irradiance data (11) from many sites in 2001, } \\
\text { divided by } 1000 \mathrm{~W} / \mathrm{m}^{2}\end{array}$} \\
\hline Wave power & \multicolumn{2}{|c|}{$\begin{array}{l}\text { Power assumed proportional to hourly average wave height at } \\
6 \text { sites of the West coast of Great Britain, (35). }\end{array}$} \\
\hline Tidal stream & \multicolumn{2}{|c|}{$\begin{array}{l}4 \text { stream cycles per } 24.84 \text { hours combined with a } 29.53 \text { day } \\
\text { cycle of spring and neap tides representing one site off the UK } \\
\text { coast. }\end{array}$} \\
\hline Tidal barrage & \multicolumn{2}{|c|}{$\begin{array}{l}2 \text { cycles per } 24.84 \text { hours (ebb generation only) combined with } \\
\text { a } 29.53 \text { day cycle of spring and neap tides representing one } \\
\text { site on the UK coast. }\end{array}$} \\
\hline $\begin{array}{l}\text { Ambient } \\
\text { Temperatures }\end{array}$ & \multicolumn{2}{|c|}{$\begin{array}{l}\text { Hourly measurements at the Rutherford Appleton Laboratory, } \\
\text { (11) but normalised using the Central England Temperature } \\
\text { Record of daily averages (36). }\end{array}$} \\
\hline $\begin{array}{l}\text { Smoothed } \\
\text { temperatures }\end{array}$ & \multicolumn{2}{|c|}{$\begin{array}{l}\text { Ambient temperatures averaged over the previous } 24 \text { hours to } \\
\text { represent temperatures as experienced by buildings with large } \\
\text { thermal masses. }\end{array}$} \\
\hline \multirow[t]{3}{*}{$\begin{array}{l}\text { Degree-hours of } \\
\text { heating or cooling }\end{array}$} & \multicolumn{2}{|c|}{$\begin{array}{l}\text { Differences between the smoothed temperatures and } \\
\text { thresholds of temperature below which / above which heating } \\
\text { or cooling is required proportional to that difference. Some } \\
\text { threshold temperatures are based on empirical evidence, } \\
\text { others on published data or from the DECC } 2050 \text { calculator. }\end{array}$} \\
\hline & $\begin{array}{l}\text { No-heat/cooling } \\
\text { temperature }\end{array}$ & Origin and description \\
\hline & $\begin{array}{l}\text { Domestic no-heat in } \\
\text { 2001: } 15.5^{\circ} \mathrm{C}\end{array}$ & $\begin{array}{l}\text { Value used by tradition and } \\
\text { convention, CIBSE (37). To } \\
\text { subtract off the correct amount of } \\
\text { domestic resistive heating from }\end{array}$ \\
\hline
\end{tabular}




\begin{tabular}{|c|c|c|}
\hline & & the demand data \\
\hline & $\begin{array}{l}\text { Domestic no-heat in other } \\
\text { years }\end{array}$ & $\begin{array}{l}\text { Changes with year. Calculated } \\
\text { from incidental heat gains and } \\
\text { internal temperatures from the } \\
\text { DECC } 2050 \text { Calculator }(10) .\end{array}$ \\
\hline & $\begin{array}{l}\text { Commercial no-heat } \\
\text { temperature in all years, } \\
14.5^{\circ} \mathrm{C}\end{array}$ & $\begin{array}{l}\text { Empirically set to give the correct } \\
\text { balance of heating by season, } \\
\text { (38). }\end{array}$ \\
\hline & $\begin{array}{l}\text { Commercial no-cool } \\
\text { temperature in all years, } \\
4^{\circ} \mathrm{C}\end{array}$ & $\begin{array}{l}\text { Empirically set to give the correct } \\
\text { balance of cooling by season (38). }\end{array}$ \\
\hline $\begin{array}{l}\text { Domestic electric } \\
\text { space heating in } \\
2001\end{array}$ & \multicolumn{2}{|c|}{$\begin{array}{l}\text { Using the domestic no-heat temperature above for year } 2001 \\
\text { smoothed ambient temperatures and the 'Economy- } 7 \text { ' daily } \\
\text { profile for space heating below, the resulting hourly demand is } \\
\text { scaled to give the annual total resistive heating of the ECUK } \\
\text { database (39) assuming that almost all domestic electric } \\
\text { heating was used under an economy- } 7 \text { tariff in } 2001 \text {. } \\
\text { This was subtracted off total electricity demand to give } \\
\text { electricity demand in } 2001 \text { excluding space heating (anc } \\
\text { excluding electric vehicle charging). }\end{array}$} \\
\hline $\begin{array}{l}\text { Domestic electric } \\
\text { water heating in } \\
2001\end{array}$ & \multicolumn{2}{|c|}{$\begin{array}{l}\text { Using the 'Economy- } 7 \text { ' daily profile for water heating below, } \\
\text { the resulting hourly demand is scaled to give the annual total } \\
\text { resistive water heating of the ECUK database (39) assuming } \\
\text { that almost all domestic electric heating was used under an } \\
\text { economy-7 tariff in } 2001 \text {. } \\
\text { This was subtracted off total electricity demand to give } \\
\text { electricity demand in excluding domestic space heating and } \\
\text { excluding domestic water heating. }\end{array}$} \\
\hline $\begin{array}{l}\text { Total domestic } \\
\text { space heating } \\
\text { demand }\end{array}$ & \multicolumn{2}{|c|}{$\begin{array}{l}\text { Degree-hours of space heating based on smoothed ambient } \\
\text { temperatures of the previous } 24 \text { hours, including variable no- } \\
\text { heat temperature and global warming changes to ambient } \\
\text { temperature as specified in the DECC } 2050 \text { Calculator. }\end{array}$} \\
\hline $\begin{array}{l}\text { Commercial electric } \\
\text { water heating in } \\
2001\end{array}$ & \multicolumn{2}{|c|}{$\begin{array}{l}\text { Using the general commercial daily profile for energy demano } \\
\text { below, the resulting hourly demand is scaled to give the } \\
\text { annual total electric water heating demand in commercia } \\
\text { buildings (heat pumps plus resistive) of the ECUK database } \\
\text { (39). } \\
\text { This was subtracted off electricity demand to give electricity } \\
\text { demand excluding commercial water heating. }\end{array}$} \\
\hline $\begin{array}{l}\text { Commercial electric } \\
\text { space heating in } \\
2001\end{array}$ & \multicolumn{2}{|c|}{$\begin{array}{l}\text { Using the general commercial daily profile for energy demanc } \\
\text { below, multiplied by the commercial degree-hours of space } \\
\text { heating, the resulting hourly demand is scaled to give the } \\
\text { annual total electric space heating demand in commercia } \\
\text { buildings (heat pumps plus resistive) of the ECUK database } \\
\text { (39). }\end{array}$} \\
\hline
\end{tabular}




\begin{tabular}{|l|l|}
\hline & $\begin{array}{l}\text { This was subtracted off total electricity demand to give } \\
\text { electricity demand excluding commercial space heating. }\end{array}$ \\
\hline $\begin{array}{l}\text { Commercial electric } \\
\text { space cooling in }\end{array} 2001$ & $\begin{array}{l}\text { Using the general commercial daily profile for energy demand } \\
\text { below, multiplied by the commercial degree-hours of space } \\
\text { cooling, the resulting hourly demand is scaled to give the } \\
\text { annual total electric space cooling demand in commercial } \\
\text { buildings (heat pumps) of the ECUK database (39). } \\
\text { This was subtracted off total electricity demand to give } \\
\text { electricity demand excluding commercial space cooling. }\end{array}$ \\
\hline
\end{tabular}

\section{A2. Table of Daily Profile Data Used in FESA}

The following inputs to FESA use 24 values, one for each hour of the day, repeated for every day of the year.

\begin{tabular}{|l|l|}
\hline Name & Description and Origin of Data \\
\hline $\begin{array}{l}\text { Hot water } \\
\text { demand }\end{array}$ & $\begin{array}{l}\text { Typical hot water demand profile for UK with a large morning peak } \\
\text { and a smaller evening peak. Based mainly on unrestricted (single } \\
\text { tariff) electricity profiles (40) but also very similar to data measured } \\
\text { by Paul Woods (41) and consistent with International Energy } \\
\text { Agency data, (42). The same profile is used for all days, week and } \\
\text { weekend. }\end{array}$ \\
\hline $\begin{array}{l}\text { Electric } \\
\text { Vehicle } \\
\text { Charging }\end{array}$ & $\begin{array}{l}\text { Approximately the inverse of transport demand profiles, (14) but } \\
\text { with reduced demand in early evening. The same profile is used for } \\
\text { all days, week and weekend. }\end{array}$ \\
\hline $\begin{array}{l}\text { Commercial } \\
\text { demand profile }\end{array}$ & $\begin{array}{l}\text { A daily demand profile with a broad peak in the middle of the day } \\
\text { (43). The same profile is used for all days, week and weekend, and } \\
\text { is an average of both week and weekend because they are very } \\
\text { similar. }\end{array}$ \\
\hline $\begin{array}{l}\text { Domestic } \\
\text { economy } 7 \text { hot } \\
\text { water profile }\end{array}$ & $\begin{array}{l}\text { Standard National Grid profile (40) from July (when space heating } \\
\text { assumed not to be required). This electricity demand is mainly in } \\
\text { the early hours of the morning. }\end{array}$ \\
\hline $\begin{array}{l}\text { Domestic } \\
\text { economy } 7 \\
\text { space heating } \\
\text { profile }\end{array}$ & $\begin{array}{l}\text { Standard National Grid profile from January (40) minus July, thus } \\
\text { subtracting off the water heating. This electricity demand is mainly } \\
\text { in the early hours of the morning. }\end{array}$ \\
\hline
\end{tabular}

\section{A3. Combinations of Annual Total Quantities with Annual Time Series and Daily Profiles}

\begin{tabular}{|ll|l|l|}
\hline $\begin{array}{ll}\text { Category of } \\
\text { Electricity }\end{array}$ & ornual Energy & Profile of Data \\
\hline
\end{tabular}




\begin{tabular}{|c|c|c|}
\hline $\begin{array}{l}\text { other } \\
\text { Demand }\end{array}$ & & \\
\hline $\begin{array}{l}\text { Appliances } \\
\text { and lighting }\end{array}$ & $\begin{array}{l}\text { Total electricity demand of } \\
\text { DECC } 2050 \text { Calculator } \\
\text { excluding heating, cooling and } \\
\text { electric vehicles }\end{array}$ & $\begin{array}{l}\text { Great Britain hourly electricity } \\
\text { demand from } 2001 \text { (12) after all } \\
\text { domestic and commercial space } \\
\text { heating, space cooling and } \\
\text { water heating profiles have been } \\
\text { subtracted off }\end{array}$ \\
\hline $\begin{array}{l}\text { Total } \\
\text { Domestic } \\
\text { space heating } \\
\text { (thermal) } \\
\text { demand }\end{array}$ & $\begin{array}{l}\text { Total domestic space heating } \\
\text { requirement of DECC } 2050 \\
\text { Calculator }\end{array}$ & $\begin{array}{l}\text { Domestic degree-hours of } \\
\text { heating based on 24-hour } \\
\text { smoothed ambient temperatures } \\
\text { and no-heat temperatures ( } 37 \text { ) } \\
\text { including incidental heat gains } \\
\text { and global warming. }\end{array}$ \\
\hline $\begin{array}{l}\text { Electricity for } \\
\text { heat pumps } \\
\text { for domestic } \\
\text { space heating }\end{array}$ & $\begin{array}{l}\text { The portion of space heating } \\
\text { provided by heat pumps }\end{array}$ & As above \\
\hline $\begin{array}{l}\text { Total domestic } \\
\text { hot water } \\
\text { demand - } \\
\text { solar }\end{array}$ & $\begin{array}{l}\text { Total domestic water heating } \\
\text { demand of DECC } 2050 \\
\text { Calculator, subtracting the } \\
\text { capped solar thermal } \\
\text { contribution. }\end{array}$ & $\begin{array}{l}\text { Daily profile of hot water } \\
\text { demand as described in table } \\
\text { A2 (large morning peak and a } \\
\text { smaller evening peak, the same } \\
\text { every day). }\end{array}$ \\
\hline $\begin{array}{l}\text { Electricity for } \\
\text { domestic heat } \\
\text { pumps for hot } \\
\text { water }\end{array}$ & $\begin{array}{l}\text { The portion of domestic hot } \\
\text { water provided by heat pumps }\end{array}$ & As above \\
\hline $\begin{array}{l}\text { Electricity for } \\
\text { domestic } \\
\text { resistive hot } \\
\text { water }\end{array}$ & $\begin{array}{l}\text { The portion of domestic hot } \\
\text { water provided by resistive } \\
\text { heating }\end{array}$ & $\begin{array}{l}\text { Same as resistive domestic hot } \\
\text { water in } 2001 \text { (economy- } 7 \text { ) (40), } \\
\text { a small sector reducing year by } \\
\text { year. }\end{array}$ \\
\hline $\begin{array}{l}\text { Electricity for } \\
\text { domestic } \\
\text { resistive space } \\
\text { heating }\end{array}$ & $\begin{array}{l}\text { The portion of domestic space } \\
\text { heating provided by resistive } \\
\text { heating }\end{array}$ & $\begin{array}{l}\text { Same as resistive domestic } \\
\text { space heating in } 2001 \\
\text { (Economy-7) (40), using degree- } \\
\text { hours of heating from } 2001 \text {, a } \\
\text { small sector, reducing year by } \\
\text { year }\end{array}$ \\
\hline $\begin{array}{l}\text { Domestic } \\
\text { boiler heat }\end{array}$ & $\begin{array}{l}\text { Total of heat from } 4 \text { types of } \\
\text { boiler: Old gas, new gas, oil and } \\
\text { solid fuel }\end{array}$ & $\begin{array}{l}\text { Sum of domestic space heating } \\
\text { and domestic water heating } \\
\text { profiles (with solar heat } \\
\text { subtracted) }\end{array}$ \\
\hline $\begin{array}{l}\text { Commercial } \\
\text { hot water } \\
\text { demand }\end{array}$ & $\begin{array}{l}\text { Annual commercial hot water } \\
\text { demand }\end{array}$ & $\begin{array}{l}\text { Commercial energy demand } \\
\text { (43) }\end{array}$ \\
\hline Commercial & Annual commercial space & Commercial space heating \\
\hline
\end{tabular}




\begin{tabular}{|l|l|l|}
\hline space heating & heating demand & $\begin{array}{l}\text { profile: A combination of } \\
\text { commercial daily profile (43) and } \\
\text { commercial degree-hours of } \\
\text { heating in each day }\end{array}$ \\
\hline $\begin{array}{l}\text { Commercial } \\
\text { and domestic } \\
\text { space cooling }\end{array}$ & $\begin{array}{l}\text { Annual commercial space } \\
\text { cooling demand plus annual } \\
\text { domestic space cooling demand }\end{array}$ & $\begin{array}{l}\text { Commercial space cooling } \\
\text { profile: A combination of } \\
\text { commercial daily profile (43) and } \\
\text { commercial degree-hours of } \\
\text { cooling (domestic uses the } \\
\text { same because cooling is } \\
\text { needed mainly during the } \\
\text { daytime and because domestic } \\
\text { space cooling remains small) }\end{array}$ \\
\hline $\begin{array}{l}\text { Total } \\
\text { electricity for } \\
\text { commercial } \\
\text { heating and } \\
\text { cooling plus } \\
\text { domestic } \\
\text { cooling }\end{array}$ & $\begin{array}{l}\text { Sum of annual electricity used in } \\
\text { commercial heat pumps and air } \\
\text { conditioning (domestic and } \\
\text { commercial) plus the extra } \\
\text { electricity used in district heating } \\
\text { systems }\end{array}$ & $\begin{array}{l}\text { Sum of weighted commercial } \\
\text { space cooling, commercial } \\
\text { water heating, commercial } \\
\text { space cooling and domestic } \\
\text { space cooling profiles }\end{array}$ \\
\hline $\begin{array}{l}\text { Commercial } \\
\text { boiler heat }\end{array}$ & $\begin{array}{l}\text { Total of heat from 4 types of } \\
\text { boiler: Old gas, new gas, oil and } \\
\text { solid fuel }\end{array}$ & $\begin{array}{l}\text { Sum of commercial space } \\
\text { heating and commercial water } \\
\text { heating profiles }\end{array}$ \\
\hline $\begin{array}{l}\text { Electricity for } \\
\text { Cars }\end{array}$ & $\begin{array}{l}\text { Electricity for Electric vehicle } \\
\text { charging }\end{array}$ & $\begin{array}{l}\text { Daily electric vehicle charging } \\
\text { profile }\end{array}$ \\
\hline $\begin{array}{l}\text { Electricity for } \\
\text { pydrogen }\end{array}$ & $\begin{array}{l}\text { Portion of hydrogen for transport } \\
\text { that is supplied by electrolysis, } \\
\text { divided by electrolyser efficiency }\end{array}$ & $\begin{array}{l}\text { A flat profile as assumed in the } \\
\text { DECC 2050 Calculator }\end{array}$ \\
\hline
\end{tabular}

\section{A4. DECC 2050 Calculator Version 3.4.6 - Quantities Used as Inputs to FESA}

\begin{tabular}{|c|c|c|c|}
\hline DECC Worksheet & Cells & Annual Quantity & Use in FESA \\
\hline $\begin{array}{l}\text { Petroleum refineries } \\
\text { XV.a }\end{array}$ & Line 133 & $\begin{array}{l}\text { Refinery own use, } \\
\text { TWh }\end{array}$ & Total liquid fuel uses \\
\hline $\begin{array}{l}\text { Industrial processes } \\
\text { XI.a }\end{array}$ & Line 242 & $\begin{array}{l}\text { Industrial uses of oil, } \\
\text { TWh }\end{array}$ & Total liquid fuel uses \\
\hline Offshore wind III.a.2 & Line 117 & $\begin{array}{l}\text { Offshore wind } \\
\text { electricity, TWh }\end{array}$ & $\begin{array}{l}\text { Offshore wind } \\
\text { electricity }\end{array}$ \\
\hline Offshore wind III.a.1 & Line 97 & $\begin{array}{l}\text { Onshore wind } \\
\text { electricity, TWh }\end{array}$ & $\begin{array}{l}\text { Onshore wind } \\
\text { electricity }\end{array}$ \\
\hline $\begin{array}{l}\text { Solar photovoltaics } \\
\text { IV.a }\end{array}$ & Line 71 & $\begin{array}{l}\text { Solar PV electricity, } \\
\text { TWh }\end{array}$ & Solar PV electricity \\
\hline Tidal and wave III.c & Line 156 & $\begin{array}{l}\text { Wave powered } \\
\text { electricity, TWh }\end{array}$ & $\begin{array}{l}\text { Wave powered } \\
\text { electricity }\end{array}$ \\
\hline
\end{tabular}




\begin{tabular}{|c|c|c|c|}
\hline Tidal and wave III.c & Line 164 & $\begin{array}{l}\text { Tidal stream electricity, } \\
\text { TWh }\end{array}$ & Tidal stream electricity \\
\hline Tidal and wave III.c & Line 172 & $\begin{array}{l}\text { Tidal range electricity, } \\
\text { TWh }\end{array}$ & $\begin{array}{l}\text { Tidal barrage } \\
\text { electricity }\end{array}$ \\
\hline $\begin{array}{l}\text { Geothermal } \\
\text { electricity III.d }\end{array}$ & Line 68 & $\begin{array}{l}\text { Geothermal generating } \\
\text { capacity, GW }\end{array}$ & $\begin{array}{l}\text { Geothermal } \\
\text { generating capacity }\end{array}$ \\
\hline $\begin{array}{l}\text { Geothermal } \\
\text { electricity III.d }\end{array}$ & Line 69 & $\begin{array}{l}\text { Geothermal } \\
\text { availability, } \%\end{array}$ & $\begin{array}{l}\text { Annual geothermal } \\
\text { electricity and } \\
\text { constant power, GW }\end{array}$ \\
\hline Nuclear Power II.a & Line 130 & $\begin{array}{l}\text { Nuclear electricity, } \\
\text { actual supplied, TWh }\end{array}$ & $\begin{array}{l}\text { Nuclear electricity } \\
\text { supplied to grid }\end{array}$ \\
\hline Nuclear Power II.a & Line 122 & $\begin{array}{l}\text { Nuclear installed } \\
\text { electrical generating } \\
\text { capacity, GW }\end{array}$ & $\begin{array}{l}\text { Nuclear installed } \\
\text { capacity }\end{array}$ \\
\hline $\begin{array}{l}\text { Storage, } \\
\text { demand shifting, } \\
\text { interconnection, VII.c }\end{array}$ & Line 167 & $\begin{array}{l}\text { Nuclear power winter } \\
\text { availability factor }\end{array}$ & $\begin{array}{l}\text { Maximum available } \\
\text { nuclear power }\end{array}$ \\
\hline $\begin{array}{l}\text { Hydroelectric power } \\
\text { stations, III.b }\end{array}$ & Line 75 & $\begin{array}{l}\text { Hydroelectric installed } \\
\text { capacity, GW }\end{array}$ & $\begin{array}{l}\text { Maximum available } \\
\text { hydroelectric power }\end{array}$ \\
\hline $\begin{array}{l}\text { Hydroelectric power } \\
\text { stations, III.b }\end{array}$ & Line 76 & $\begin{array}{l}\text { Hydroelectric average } \\
\text { capacity factor }\end{array}$ & $\begin{array}{l}\text { Average hydroelectric } \\
\text { electricity to grid }\end{array}$ \\
\hline $\begin{array}{l}\text { Domestic passenger } \\
\text { transport, XII.a }\end{array}$ & Line 763 & $\begin{array}{l}\text { Liquid hydrocarbons } \\
\text { for domestic aviation, } \\
\text { TWh }\end{array}$ & Total liquid fuel uses \\
\hline $\begin{array}{l}\text { Domestic freight, } \\
\text { XII.b }\end{array}$ & Line 375 & $\begin{array}{l}\text { Liquid hydrocarbons } \\
\text { for national navigation, } \\
\text { TWh }\end{array}$ & Total liquid fuel uses \\
\hline $\begin{array}{l}\text { International aviation, } \\
\text { XII.c }\end{array}$ & Line 106 & $\begin{array}{l}\text { Liquid hydrocarbons } \\
\text { for international } \\
\text { aviation, TWh }\end{array}$ & Total liquid fuel uses \\
\hline $\begin{array}{l}\text { International } \\
\text { shipping, XII.e }\end{array}$ & Line 95 & $\begin{array}{l}\text { Liquid hydrocarbons } \\
\text { for shipping, TWh }\end{array}$ & Total liquid fuel uses \\
\hline $\begin{array}{l}\text { Domestic freight, } \\
\text { XII.b }\end{array}$ & Line 360 & $\begin{array}{l}\text { Liquid hydrocarbons } \\
\text { for road freight, TWh }\end{array}$ & Total liquid fuel uses \\
\hline $\begin{array}{l}\text { Domestic passenger } \\
\text { transport, XII.a }\end{array}$ & Line 745 & $\begin{array}{l}\text { Liquid hydrocarbons } \\
\text { for road passenger } \\
\text { transport, TWh }\end{array}$ & Total liquid fuel uses \\
\hline $\begin{array}{l}\text { Domestic freight, } \\
\text { XII.b }\end{array}$ & Line 368 & $\begin{array}{l}\text { Liquid hydrocarbons } \\
\text { for rail freight, TWh }\end{array}$ & Total liquid fuel uses \\
\hline $\begin{array}{l}\text { Domestic passenger } \\
\text { transport, XII.a }\end{array}$ & Line 754 & $\begin{array}{l}\text { Liquid hydrocarbons } \\
\text { for rail passenger } \\
\text { transport, TWh }\end{array}$ & Total liquid fuel uses \\
\hline $\begin{array}{l}\text { Domestic passenger } \\
\text { transport, XII.a }\end{array}$ & Line 152 & $\begin{array}{l}\text { Electricity per mile, } \\
\text { TWh/bn km (kWh/km) }\end{array}$ & $\begin{array}{l}\text { Total miles powered } \\
\text { by electricity }\end{array}$ \\
\hline $\begin{array}{l}\text { Domestic freight, } \\
\text { XII.b }\end{array}$ & Line 228 & $\begin{array}{l}\text { Electricity for road } \\
\text { freight, TWh }\end{array}$ & $\begin{array}{l}\text { Electricity for road } \\
\text { transport }\end{array}$ \\
\hline $\begin{array}{l}\text { Domestic passenger } \\
\text { transport, XII.a }\end{array}$ & Line 746 & $\begin{array}{l}\text { Electricity for road } \\
\text { passenger transport, } \\
\text { TWh }\end{array}$ & $\begin{array}{l}\text { Electricity for road } \\
\text { transport }\end{array}$ \\
\hline
\end{tabular}




\begin{tabular}{|c|c|c|c|}
\hline $\begin{array}{l}\text { Storage, } \\
\text { demand shifting, } \\
\text { interconnection, VII.c }\end{array}$ & Line 245 & $\begin{array}{l}\text { Shifting demand from } \\
\text { electric vehicles, GW }\end{array}$ & $\begin{array}{l}\text { Loads that can be } \\
\text { time-shifted for grid } \\
\text { balancing }\end{array}$ \\
\hline $\begin{array}{l}\text { Domestic passenger } \\
\text { transport, XII.a }\end{array}$ & Line 755 & $\begin{array}{l}\text { Electricity for rail } \\
\text { passenger transport, } \\
\text { TWh }\end{array}$ & $\begin{array}{l}\text { Electricity for rail } \\
\text { transport }\end{array}$ \\
\hline $\begin{array}{l}\text { Domestic freight, } \\
\text { XII.b }\end{array}$ & Line 367 & $\begin{array}{l}\text { Electricity for rail } \\
\text { freight transport, TWh }\end{array}$ & $\begin{array}{l}\text { Electricity for rail } \\
\text { transport }\end{array}$ \\
\hline $\begin{array}{l}\text { Hydrogen production } \\
\text { for transport, VIII.a }\end{array}$ & Line 116 & $\begin{array}{l}\text { Hydrogen required for } \\
\text { transport, TWh }\end{array}$ & $\begin{array}{l}\text { Hydrogen required for } \\
\text { transport }\end{array}$ \\
\hline $\begin{array}{l}\text { Domestic passenger } \\
\text { transport, XII.a }\end{array}$ & Line 159 & $\begin{array}{l}\text { Hydrogen per mile, } \\
\text { TWh/bn km (kWh/km) }\end{array}$ & $\begin{array}{l}\text { Order-of-magnitude } \\
\text { checks }\end{array}$ \\
\hline Solar Thermal, IV.b & Line 62 & Number of households & $\begin{array}{l}\text { Number of roofs with } \\
\text { solar water heating }\end{array}$ \\
\hline $\begin{array}{l}\text { Domestic space } \\
\text { heating and hot } \\
\text { water, IX.a }\end{array}$ & $\begin{array}{l}\text { Lines } 109 \\
\text { to } 112\end{array}$ & $\begin{array}{l}\text { Average external } \\
\text { temperatures in each } \\
\text { season, }{ }^{\circ} \mathrm{C}\end{array}$ & $\begin{array}{l}\text { External temperature } \\
\text { rise due to climate } \\
\text { change }\end{array}$ \\
\hline $\begin{array}{l}\text { Domestic space } \\
\text { heating and hot } \\
\text { water, IX.a }\end{array}$ & Line 822 & $\begin{array}{l}\text { Incidental heat gains in } \\
\text { homes, Joules/home }\end{array}$ & $\begin{array}{l}\text { The "no-heat" } \\
\text { temperature above } \\
\text { which space heating } \\
\text { is not required. }\end{array}$ \\
\hline $\begin{array}{l}\text { Domestic space } \\
\text { heating and hot } \\
\text { water, IX.a }\end{array}$ & Line 71 & $\begin{array}{l}\text { Heat loss rate per } \\
\text { home, } \mathrm{W} /{ }^{\circ} \mathrm{C} / \text { home }\end{array}$ & $\begin{array}{l}\text { The "no-heat" } \\
\text { temperature. }\end{array}$ \\
\hline $\begin{array}{l}\text { Domestic space } \\
\text { heating and hot } \\
\text { water, IX.a }\end{array}$ & Line 44 & $\begin{array}{l}\text { Average internal } \\
\text { temperature of homes }\end{array}$ & $\begin{array}{l}\text { The "no-heat" } \\
\text { temperature. }\end{array}$ \\
\hline $\begin{array}{l}\text { Domestic space } \\
\text { heating and hot } \\
\text { water, IX.a }\end{array}$ & $\begin{array}{l}\text { Lines } 1173 \\
\text { and } 1174\end{array}$ & $\begin{array}{l}\text { CHP electricity to end } \\
\text { user and to grid } \\
\text { respectively, TWh }\end{array}$ & Electricity from CHP \\
\hline $\begin{array}{l}\text { Domestic space } \\
\text { heating and hot } \\
\text { water, IX.a }\end{array}$ & Line 1181 & $\begin{array}{l}\text { CHP heating and } \\
\text { cooling, TWh }\end{array}$ & $\begin{array}{l}\text { Domestic heat from } \\
\text { CHP }\end{array}$ \\
\hline $\begin{array}{l}\text { Domestic space } \\
\text { heating and hot } \\
\text { water, IX.a }\end{array}$ & Line 1175 & $\begin{array}{l}\text { Solid fuel used by } \\
\text { CHP, TWh }\end{array}$ & Solid fuel used \\
\hline $\begin{array}{l}\text { Domestic space } \\
\text { heating and hot } \\
\text { water, IX.a }\end{array}$ & Line 1176 & $\begin{array}{l}\text { Liquid fuel used by } \\
\text { CHP, TWh }\end{array}$ & Liquid fuel used \\
\hline $\begin{array}{l}\text { Domestic space } \\
\text { heating and hot } \\
\text { water, IX.a }\end{array}$ & Line 1177 & $\begin{array}{l}\text { Gaseous fuel used by } \\
\text { CHP, TWh }\end{array}$ & Natural gas used \\
\hline $\begin{array}{l}\text { Domestic space } \\
\text { heating and hot } \\
\text { water, IX.a }\end{array}$ & Line 835 & $\begin{array}{l}\text { Electricity used for } \\
\text { domestic resistive } \\
\text { space heating, TWh }\end{array}$ & $\begin{array}{l}\text { Electricity used for } \\
\text { domestic resistive } \\
\text { space heating }\end{array}$ \\
\hline $\begin{array}{l}\text { Domestic space } \\
\text { heating and hot } \\
\text { water, IX.a }\end{array}$ & Line 765 & $\begin{array}{l}\text { Electricity used for } \\
\text { domestic resistive } \\
\text { water heating, TWh }\end{array}$ & $\begin{array}{l}\text { Electricity used for } \\
\text { domestic resistive } \\
\text { water heating }\end{array}$ \\
\hline Domestic space & Lines 840 & Domestic space heat & Electricity used in \\
\hline
\end{tabular}




\begin{tabular}{|c|c|c|c|}
\hline $\begin{array}{l}\text { heating and hot } \\
\text { water, IX.a }\end{array}$ & and 841 & $\begin{array}{l}\text { from air-source and } \\
\text { ground-source heat } \\
\text { pumps respectively, } \\
\text { TWh }\end{array}$ & $\begin{array}{l}\text { domestic heat pumps } \\
\text { for space heating. } \\
\text { COPs assumed from } \\
\text { Calculator Wiki pages, } \\
3: 1 \text { for air-source and } \\
\text { 4:1 for ground-source }\end{array}$ \\
\hline $\begin{array}{l}\text { Domestic space } \\
\text { heating and hot } \\
\text { water, IX.a }\end{array}$ & $\begin{array}{l}\text { Lines } 770 \\
\text { and } 771\end{array}$ & $\begin{array}{l}\text { Domestic water heat } \\
\text { from air-source and } \\
\text { ground-source heat } \\
\text { pumps respectively, } \\
\text { TWh }\end{array}$ & $\begin{array}{l}\text { Electricity used in } \\
\text { domestic heat pumps } \\
\text { for water heating. } \\
\text { COPs assumed from } \\
\text { Calculator Wiki pages, } \\
\text { 2:1 for air-source and } \\
3: 1 \text { for ground-source }\end{array}$ \\
\hline $\begin{array}{l}\text { Domestic space } \\
\text { heating and hot } \\
\text { water, IX.a }\end{array}$ & Line 1195 & $\begin{array}{l}\text { Environmental heat } \\
\text { gathered (by heat } \\
\text { pumps) }\end{array}$ & $\begin{array}{l}\text { Checking that energy } \\
\text { adds up }\end{array}$ \\
\hline $\begin{array}{l}\text { Domestic space } \\
\text { heating and hot } \\
\text { water, IX.a }\end{array}$ & $\begin{array}{l}\text { Lines } 763 \\
\text { and } 833\end{array}$ & $\begin{array}{l}\text { Domestic heat from old } \\
\text { gas boilers to water } \\
\text { heating and space } \\
\text { heating respectively, } \\
\text { TWh }\end{array}$ & $\begin{array}{l}\text { Total fuelled heat } \\
\text { supply (not directly } \\
\text { needed until fuel } \\
\text { switching is used for } \\
\text { grid-balancing) }\end{array}$ \\
\hline $\begin{array}{l}\text { Domestic space } \\
\text { heating and hot } \\
\text { water, IX.a }\end{array}$ & $\begin{array}{l}\text { Lines } 764 \\
\text { and } 834\end{array}$ & $\begin{array}{l}\text { Domestic heat from } \\
\text { new gas boilers to } \\
\text { water heating and } \\
\text { space heating } \\
\text { respectively, TWh }\end{array}$ & $\begin{array}{l}\text { Total fuelled heat } \\
\text { supply (not directly } \\
\text { needed until fuel } \\
\text { switching is used for } \\
\text { grid-balancing) }\end{array}$ \\
\hline $\begin{array}{l}\text { Domestic space } \\
\text { heating and hot } \\
\text { water, IX.a }\end{array}$ & $\begin{array}{l}\text { Lines } 766 \\
\text { and } 836\end{array}$ & $\begin{array}{l}\text { Domestic heat from oil } \\
\text { fired boilers to water } \\
\text { heating and space } \\
\text { heating respectively, } \\
\text { TWh }\end{array}$ & $\begin{array}{l}\text { Total fuelled heat } \\
\text { supply (not directly } \\
\text { needed until fuel } \\
\text { switching is used for } \\
\text { grid-balancing) }\end{array}$ \\
\hline $\begin{array}{l}\text { Domestic space } \\
\text { heating and hot } \\
\text { water, IX.a }\end{array}$ & $\begin{array}{l}\text { Lines } 767 \\
\text { and } 837\end{array}$ & $\begin{array}{l}\text { Domestic heat from } \\
\text { solid fuelled boilers to } \\
\text { water heating and } \\
\text { space heating } \\
\text { respectively, TWh }\end{array}$ & $\begin{array}{l}\text { Total fuelled heat } \\
\text { supply (not directly } \\
\text { needed until fuel } \\
\text { switching is used for } \\
\text { grid-balancing) }\end{array}$ \\
\hline $\begin{array}{l}\text { Domestic space } \\
\text { heating and hot } \\
\text { water, IX.a }\end{array}$ & Line 1161 & $\begin{array}{l}\text { Solid fuel used in } \\
\text { domestic boilers, TWh }\end{array}$ & Total solid fuel used \\
\hline $\begin{array}{l}\text { Domestic space } \\
\text { heating and hot } \\
\text { water, IX.a }\end{array}$ & Line 1162 & $\begin{array}{l}\text { Liquid fuel used in } \\
\text { domestic boilers, TWh }\end{array}$ & Total liquid fuel used \\
\hline $\begin{array}{l}\text { Domestic space } \\
\text { heating and hot } \\
\text { water, IX.a }\end{array}$ & Line 1163 & $\begin{array}{l}\text { Gaseous fuel used in } \\
\text { domestic boilers, TWh }\end{array}$ & Total natural gas used \\
\hline $\begin{array}{l}\text { Domestic space } \\
\text { heating and hot } \\
\text { water, IX.a }\end{array}$ & Line 755 & $\begin{array}{l}\text { Total domestic hot } \\
\text { water demand, TWh }\end{array}$ & $\begin{array}{l}\text { Total water heating } \\
\text { demand, and } \\
\text { maximum that can be } \\
\text { displaced by solar } \\
\text { thermal heat }\end{array}$ \\
\hline
\end{tabular}




\begin{tabular}{|c|c|c|c|}
\hline $\begin{array}{l}\text { Domestic space } \\
\text { heating and hot } \\
\text { water, IX.a }\end{array}$ & Line 828 & $\begin{array}{l}\text { Total domestic space } \\
\text { heating demand, TWh }\end{array}$ & $\begin{array}{l}\text { Total space heating } \\
\text { demand }\end{array}$ \\
\hline $\begin{array}{l}\text { Domestic space } \\
\text { heating and hot } \\
\text { water, IX.a }\end{array}$ & Line 886 & $\begin{array}{l}\text { Total domestic space } \\
\text { cooling demand, TWh }\end{array}$ & $\begin{array}{l}\text { Total space cooling } \\
\text { demand }\end{array}$ \\
\hline $\begin{array}{l}\text { Commercial heating } \\
\text { and cooling, IX.c }\end{array}$ & $\begin{array}{l}\text { Lines } 719 \\
\text { and } 720\end{array}$ & $\begin{array}{l}\text { CHP electricity to end } \\
\text { user and to grid } \\
\text { respectively, TWh }\end{array}$ & Electricity from CHP \\
\hline $\begin{array}{l}\text { Commercial heating } \\
\text { and cooling, IX.C }\end{array}$ & Line 726 & $\begin{array}{l}\text { CHP heating and } \\
\text { cooling, TWh }\end{array}$ & $\begin{array}{l}\text { Domestic heat from } \\
\text { CHP }\end{array}$ \\
\hline $\begin{array}{l}\text { Commercial heating } \\
\text { and cooling, IX.c }\end{array}$ & Line 721 & $\begin{array}{l}\text { Solid fuel used by } \\
\text { CHP, TWh }\end{array}$ & Solid fuel used \\
\hline $\begin{array}{l}\text { Commercial heating } \\
\text { and cooling, IX.c }\end{array}$ & Line 722 & $\begin{array}{l}\text { Liquid fuel used by } \\
\text { CHP, TWh }\end{array}$ & Liquid fuel used \\
\hline $\begin{array}{l}\text { Commercial heating } \\
\text { and cooling, IX.C }\end{array}$ & Line 723 & $\begin{array}{l}\text { Gaseous fuel used by } \\
\text { CHP, TWh }\end{array}$ & Natural gas used \\
\hline $\begin{array}{l}\text { Commercial heating } \\
\text { and cooling, IX.C }\end{array}$ & Line 705 & $\begin{array}{l}\text { Electricity used in } \\
\text { commercial heating } \\
\text { and cooling }\end{array}$ & $\begin{array}{l}\text { Electricity used in } \\
\text { commercial buildings }\end{array}$ \\
\hline $\begin{array}{l}\text { District heating } \\
\text { demand XVII.a }\end{array}$ & Line 49 & $\begin{array}{l}\text { Electricity used in } \\
\text { district heating, TWh }\end{array}$ & $\begin{array}{l}\text { An addition to } \\
\text { commercial electricity }\end{array}$ \\
\hline $\begin{array}{l}\text { Commercial heating } \\
\text { and cooling, IX.c }\end{array}$ & Line 739 & $\begin{array}{l}\text { Environmental heat } \\
\text { gathered (by heat } \\
\text { pumps) }\end{array}$ & $\begin{array}{l}\text { Checking that energy } \\
\text { adds up }\end{array}$ \\
\hline $\begin{array}{l}\text { Commercial heating } \\
\text { and cooling, IX.c }\end{array}$ & $\begin{array}{l}\text { Lines } 350 \\
\text { and } 382\end{array}$ & $\begin{array}{l}\text { Commercial heat from } \\
\text { old gas boilers to water } \\
\text { heating and space } \\
\text { heating respectively, } \\
\text { TWh }\end{array}$ & $\begin{array}{l}\text { Total fuelled heat } \\
\text { supply (not directly } \\
\text { needed until fuel } \\
\text { switching is used for } \\
\text { grid-balancing) }\end{array}$ \\
\hline $\begin{array}{l}\text { Commercial heating } \\
\text { and cooling, IX.c }\end{array}$ & $\begin{array}{l}\text { Lines } 351 \\
\text { and } 383\end{array}$ & $\begin{array}{l}\text { Commercial heat from } \\
\text { new gas boilers to } \\
\text { water heating and } \\
\text { space heating } \\
\text { respectively, TWh }\end{array}$ & $\begin{array}{l}\text { Total fuelled heat } \\
\text { supply (not directly } \\
\text { needed until fuel } \\
\text { switching is used for } \\
\text { grid-balancing) }\end{array}$ \\
\hline $\begin{array}{l}\text { Commercial heating } \\
\text { and cooling, IX.c }\end{array}$ & $\begin{array}{l}\text { Lines } 353 \\
\text { and } 385\end{array}$ & $\begin{array}{l}\text { Commercial heat from } \\
\text { oil fired boilers to water } \\
\text { heating and space } \\
\text { heating respectively, } \\
\text { TWh }\end{array}$ & $\begin{array}{l}\text { Total fuelled heat } \\
\text { supply (not directly } \\
\text { needed until fuel } \\
\text { switching is used for } \\
\text { grid-balancing) }\end{array}$ \\
\hline $\begin{array}{l}\text { Commercial heating } \\
\text { and cooling, IX.c }\end{array}$ & $\begin{array}{l}\text { Lines } 354 \\
\text { and } 386\end{array}$ & $\begin{array}{l}\text { Commercial heat from } \\
\text { coal fired boilers to } \\
\text { water heating and } \\
\text { space heating } \\
\text { respectively, TWh }\end{array}$ & $\begin{array}{l}\text { Total fuelled heat } \\
\text { supply (not directly } \\
\text { needed until fuel } \\
\text { switching is used for } \\
\text { grid-balancing) }\end{array}$ \\
\hline $\begin{array}{l}\text { Commercial heating } \\
\text { and cooling, IX.C }\end{array}$ & Line 707 & $\begin{array}{l}\text { Solid fuel used in } \\
\text { commercial boilers, } \\
\text { TWh }\end{array}$ & Total solid fuel used \\
\hline Commercial heating & Line 708 & Liquid fuel used in & Total liquid fuel used \\
\hline
\end{tabular}




\begin{tabular}{|c|c|c|c|}
\hline and cooling, IX.C & & $\begin{array}{l}\text { commercial boilers, } \\
\text { TWh }\end{array}$ & \\
\hline $\begin{array}{l}\text { Commercial heating } \\
\text { and cooling, IX.c }\end{array}$ & Line 709 & $\begin{array}{l}\text { Gaseous fuel used in } \\
\text { commercial boilers, } \\
\text { TWh }\end{array}$ & Total natural gas used \\
\hline $\begin{array}{l}\text { Commercial heating } \\
\text { and cooling, IX.c }\end{array}$ & Line 363 & $\begin{array}{l}\text { Total commercial hot } \\
\text { water demand, TWh }\end{array}$ & $\begin{array}{l}\text { Total water heating } \\
\text { demand }\end{array}$ \\
\hline $\begin{array}{l}\text { Commercial heating } \\
\text { and cooling, IX.c }\end{array}$ & Line 395 & $\begin{array}{l}\text { Total commercial } \\
\text { space heating } \\
\text { demand, TWh }\end{array}$ & $\begin{array}{l}\text { Total space heating } \\
\text { demand }\end{array}$ \\
\hline $\begin{array}{l}\text { Commercial heating } \\
\text { and cooling, IX.c }\end{array}$ & Line 418 & $\begin{array}{l}\text { Total commercial } \\
\text { space cooling demand, } \\
\text { TWh }\end{array}$ & $\begin{array}{l}\text { Total space cooling } \\
\text { demand }\end{array}$ \\
\hline Solar thermal, IV.b & Line 76 & $\begin{array}{l}\text { Number of dwellings } \\
\text { with solar thermal }\end{array}$ & Solar hot water power \\
\hline $\begin{array}{l}\text { Domestic Lighting } \\
\text { and appliances, X.a }\end{array}$ & Line 132 & $\begin{array}{l}\text { Gas used in cooking \& } \\
\text { appliances, TWh }\end{array}$ & $\begin{array}{l}\text { Natural gas used for } \\
\text { cooking \& appliances }\end{array}$ \\
\hline $\begin{array}{l}\text { Domestic Lighting } \\
\text { and appliances, X.a }\end{array}$ & Line 118 & $\begin{array}{l}\text { Electricity used in } \\
\text { cooking, TWh }\end{array}$ & $\begin{array}{l}\text { Electricity used for } \\
\text { cooking }\end{array}$ \\
\hline $\begin{array}{l}\text { Commercial Lighting } \\
\text { and appliances, X.b }\end{array}$ & Line 155 & $\begin{array}{l}\text { Gas used in cooking \& } \\
\text { appliances, TWh }\end{array}$ & $\begin{array}{l}\text { Natural gas used for } \\
\text { cooking \& appliances }\end{array}$ \\
\hline $\begin{array}{l}\text { Commercial Lighting } \\
\text { and appliances, X.b }\end{array}$ & Line 104 & $\begin{array}{l}\text { Electricity used in } \\
\text { cooking, TWh }\end{array}$ & $\begin{array}{l}\text { Electricity used for } \\
\text { cooking }\end{array}$ \\
\hline $\begin{array}{l}\text { Domestic Lighting } \\
\text { and appliances, X.a }\end{array}$ & Line 131 & $\begin{array}{l}\text { Domestic electricity for } \\
\text { appliances, TWh }\end{array}$ & $\begin{array}{l}\text { Electricity used in } \\
\text { domestic appliances }\end{array}$ \\
\hline Solar thermal, IV.b & Line 76 & $\begin{array}{l}\text { Electricity used for } \\
\text { solar thermal pumping }\end{array}$ & $\begin{array}{l}\text { Electricity used in } \\
\text { domestic appliances }\end{array}$ \\
\hline $\begin{array}{l}\text { Commercial Lighting } \\
\text { and appliances, X.b }\end{array}$ & Line 115 & $\begin{array}{l}\text { Commercial electricity } \\
\text { for appliances, TWh }\end{array}$ & $\begin{array}{l}\text { Commercial electricity } \\
\text { use }\end{array}$ \\
\hline $\begin{array}{l}\text { Industrial processes, } \\
\text { XI.a }\end{array}$ & Line 240 & Electricity used, TWh & $\begin{array}{l}\text { Electricity used by } \\
\text { industry }\end{array}$ \\
\hline $\begin{array}{l}\text { Petroleum refineries, } \\
\text { XV.a }\end{array}$ & Line 132 & Electricity used, TWh & $\begin{array}{l}\text { Electricity used by } \\
\text { industry }\end{array}$ \\
\hline $\begin{array}{l}\text { Indigenous fossil fuel } \\
\text { production } X V . b\end{array}$ & Line 208 & Electricity used, TWh & $\begin{array}{l}\text { Electricity used by } \\
\text { industry }\end{array}$ \\
\hline Agriculture, VI.a & Line 536 & Electricity used, TWh & $\begin{array}{l}\text { Electricity used by } \\
\text { agriculture }\end{array}$ \\
\hline $\begin{array}{l}\text { Electricity grid } \\
\text { distribution, VII.b }\end{array}$ & Line 117 & $\begin{array}{l}\text { Distribution losses and } \\
\text { own use, TWh }\end{array}$ & $\begin{array}{l}\text { Distribution losses } \\
\text { and own use }\end{array}$ \\
\hline $\begin{array}{l}\text { Electricity storage, } \\
\text { demand shifting, } \\
\text { interconnection, VII.c }\end{array}$ & Line 434 & $\begin{array}{l}\text { Distribution losses and } \\
\text { own use, TWh }\end{array}$ & $\begin{array}{l}\text { Storage losses and } \\
\text { own use }\end{array}$ \\
\hline $\begin{array}{l}\text { Geosequestration } \\
\text { (CCS), XIV.a }\end{array}$ & Line 168 & Electricity used, TWh & $\begin{array}{l}\text { Electricity used for } \\
\text { Geosequestration }\end{array}$ \\
\hline $\begin{array}{l}\text { Electricity imports, } \\
\text { VII.a }\end{array}$ & Line 20 & $\begin{array}{l}\text { Interconnector } \\
\text { capacity, GW }\end{array}$ & $\begin{array}{l}\text { Interconnector export } \\
\text { capacity }\end{array}$ \\
\hline $\begin{array}{l}\text { Electricity storage, } \\
\text { demand shifting, } \\
\text { interconnection, VII.c }\end{array}$ & Line 244 & $\begin{array}{l}\text { Power capacity from } \\
\text { interconnection, GW }\end{array}$ & $\begin{array}{l}\text { Interconnector import } \\
\text { capacity }\end{array}$ \\
\hline
\end{tabular}




\begin{tabular}{|c|c|c|c|}
\hline $\begin{array}{l}\text { Electricity imports, } \\
\text { VII.a }\end{array}$ & Line 120 & $\begin{array}{l}\text { Imported electricity, } \\
\text { TWh }\end{array}$ & $\begin{array}{l}\text { Planned (routine) } \\
\text { electricity imports }\end{array}$ \\
\hline $\begin{array}{l}\text { Electricity storage, } \\
\text { demand shifting, } \\
\text { interconnection, VII.c }\end{array}$ & Line 246 & $\begin{array}{l}\text { Power capacity from } \\
\text { pumped storage, GW }\end{array}$ & $\begin{array}{l}\text { Pumped storage } \\
\text { capacity }\end{array}$ \\
\hline $\begin{array}{l}\text { Hydrogen production } \\
\text { for transport, VIII.a }\end{array}$ & Line 119 & $\begin{array}{l}\text { Hydrogen from } \\
\text { electrolysis, TWh }\end{array}$ & $\begin{array}{l}\text { Electrolytic hydrogen } \\
\text { for transport }\end{array}$ \\
\hline $\begin{array}{l}\text { Hydrogen production } \\
\text { for transport, VIII.a }\end{array}$ & Line 139 & $\begin{array}{l}\text { Electrolyser power, } \\
\text { GW }\end{array}$ & Electrolyser capacity \\
\hline $\begin{array}{l}\text { Hydrogen production } \\
\text { for transport, VIII.a }\end{array}$ & Line 19 & $\begin{array}{l}\text { Electrolyser } \\
\text { efficiency, \% }\end{array}$ & Electrolyser efficiency \\
\hline $\begin{array}{l}\text { Biomass / coal power } \\
\text { stations, I.a }\end{array}$ & Line 197 & $\begin{array}{l}\text { Biomass installed } \\
\text { capacity, GW }\end{array}$ & $\begin{array}{l}\text { Rated Biomass } \\
\text { generating capacity }\end{array}$ \\
\hline $\begin{array}{l}\text { Biomass / coal power } \\
\text { stations, I.a }\end{array}$ & Line 209 & Implied load factor, \% & $\begin{array}{l}\text { Maximum biomass } \\
\text { availability factor }\end{array}$ \\
\hline $\begin{array}{l}\text { Carbon capture and } \\
\text { storage, I.b }\end{array}$ & $\begin{array}{l}\text { Lines } 217 \\
\text { and } 218\end{array}$ & $\begin{array}{l}\text { Gas-fired generating } \\
\text { capacity and CCS use } \\
\text { respectively, GW }\end{array}$ & $\begin{array}{l}\text { Rated generating } \\
\text { capacity of CCGT with } \\
\text { CCS }\end{array}$ \\
\hline $\begin{array}{l}\text { Electricity storage, } \\
\text { demand shifting, } \\
\text { interconnection, VII.c }\end{array}$ & Line 163 & $\begin{array}{l}\text { CCGT maximum } \\
\text { availability factor, \% }\end{array}$ & $\begin{array}{l}\text { Maximum availability } \\
\text { factor of CCGT with or } \\
\text { without CCS }\end{array}$ \\
\hline $\begin{array}{l}\text { Carbon capture and } \\
\text { storage, I.b }\end{array}$ & $\begin{array}{l}\text { Lines } 188 \\
\text { and } 189\end{array}$ & $\begin{array}{l}\text { Post combustion CCS } \\
\text { coal-fired generating } \\
\text { capacity and CCS use } \\
\text { respectively, GW }\end{array}$ & $\begin{array}{l}\text { Rated generating } \\
\text { capacity of coal with } \\
\text { post-combustion CCS }\end{array}$ \\
\hline $\begin{array}{l}\text { Carbon capture and } \\
\text { storage, I.b }\end{array}$ & $\begin{array}{l}\text { Lines } 203 \\
\text { and } 204\end{array}$ & $\begin{array}{l}\text { Pre combustion CCS } \\
\text { coal-fired generating } \\
\text { capacity and CCS use } \\
\text { respectively, GW }\end{array}$ & $\begin{array}{l}\text { Rated generating } \\
\text { capacity of coal with } \\
\text { pre-combustion CCS }\end{array}$ \\
\hline $\begin{array}{l}\text { Electricity storage, } \\
\text { demand shifting, } \\
\text { interconnection, VII.c }\end{array}$ & Line 166 & $\begin{array}{l}\text { CCS maximum } \\
\text { availability factor, \% }\end{array}$ & $\begin{array}{l}\text { Maximum availability } \\
\text { factor of coal with } \\
\text { CCS }\end{array}$ \\
\hline $\begin{array}{l}\text { Biomass / coal power } \\
\text { stations, I.a }\end{array}$ & Line 281 & $\begin{array}{l}\text { Rated capacity of gas- } \\
\text { fired generation, GW }\end{array}$ & $\begin{array}{l}\text { Rated capacity of } \\
\text { CCGT without CCS }\end{array}$ \\
\hline $\begin{array}{l}\text { Biomass / coal power } \\
\text { stations, I.a }\end{array}$ & Line 196 & $\begin{array}{l}\text { Generating capacity of } \\
\text { coal without CCS, GW }\end{array}$ & $\begin{array}{l}\text { Generating capacity } \\
\text { of coal without CCS }\end{array}$ \\
\hline $\begin{array}{l}\text { Electricity storage, } \\
\text { demand shifting, } \\
\text { interconnection, VII.c }\end{array}$ & Line 165 & $\begin{array}{l}\text { Coal without CCS } \\
\text { maximum availability } \\
\text { factor, } \%\end{array}$ & $\begin{array}{l}\text { Maximum availability } \\
\text { factor of coal without } \\
\text { CCS }\end{array}$ \\
\hline $\begin{array}{l}\text { Biomass / coal power } \\
\text { stations, I.a }\end{array}$ & Line 279 & $\begin{array}{l}\text { Generating capacity of } \\
\text { oil without CCS, GW }\end{array}$ & $\begin{array}{l}\text { Generating capacity } \\
\text { of oil without CCS }\end{array}$ \\
\hline $\begin{array}{l}\text { Electricity storage, } \\
\text { demand shifting, } \\
\text { interconnection, VII.c }\end{array}$ & Line 164 & $\begin{array}{l}\text { Oil-fired generation } \\
\text { maximum availability } \\
\text { factor, } \%\end{array}$ & $\begin{array}{l}\text { Maximum availability } \\
\text { factor of oil-fired } \\
\text { generation }\end{array}$ \\
\hline $\begin{array}{l}\text { Electricity storage, } \\
\text { demand shifting, } \\
\text { interconnection, VII.c }\end{array}$ & Line 390 & $\begin{array}{l}\text { Generating capacity of } \\
\text { gas-fired OCGT } \\
\text { without CCS, GW }\end{array}$ & $\begin{array}{l}\text { Generating capacity } \\
\text { of gas-fired OCGT } \\
\text { without CCS }\end{array}$ \\
\hline $\begin{array}{l}\text { Electricity storage, } \\
\text { demand shifting, }\end{array}$ & Line 153 & $\begin{array}{l}\text { gas-fired OCGT } \\
\text { without CCS maximum }\end{array}$ & $\begin{array}{l}\text { gas-fired OCGT } \\
\text { maximum availability }\end{array}$ \\
\hline
\end{tabular}




\begin{tabular}{|c|c|c|c|}
\hline interconnection, VII.c & & availability factor, \% & factor \\
\hline $\begin{array}{l}\text { Biomass / coal power } \\
\text { stations, I.a }\end{array}$ & $\begin{array}{l}\text { Lines } 60 \\
\text { and } 53\end{array}$ & $\begin{array}{l}\text { Thermal efficiency and } \\
\text { self-use of gas CCGT }\end{array}$ & $\begin{array}{l}\text { Overall efficiency of } \\
\text { gas-fired CCGT }\end{array}$ \\
\hline $\begin{array}{l}\text { Biomass / coal power } \\
\text { stations, I.a }\end{array}$ & $\begin{array}{l}\text { Lines } 58 \\
\text { and } 51\end{array}$ & $\begin{array}{l}\text { Thermal efficiency and } \\
\text { self-use of coal \& } \\
\text { biomass power, } \%\end{array}$ & $\begin{array}{l}\text { Overall efficiency of } \\
\text { coal and biomass } \\
\text { generation }\end{array}$ \\
\hline $\begin{array}{l}\text { Carbon capture and } \\
\text { storage, I.b }\end{array}$ & $\begin{array}{l}\text { Lines } 56 \\
\text { and } 70\end{array}$ & $\begin{array}{l}\text { Unabated efficiency } \\
\text { and CCS / self-use } \\
\text { load of CCGT CCS, \% }\end{array}$ & $\begin{array}{l}\text { Overall efficiency of } \\
\text { CCGT with CCS }\end{array}$ \\
\hline $\begin{array}{l}\text { Carbon capture and } \\
\text { storage, I.b }\end{array}$ & $\begin{array}{l}\text { Lines } 55 \\
\text { and } 69\end{array}$ & $\begin{array}{l}\text { Unabated efficiency } \\
\text { and CCS / self-use } \\
\text { load of coal with pre- } \\
\text { combustion CCS, \% }\end{array}$ & $\begin{array}{l}\text { Overall efficiency of } \\
\text { coal with pre- } \\
\text { combustion CCS }\end{array}$ \\
\hline $\begin{array}{l}\text { Carbon capture and } \\
\text { storage, I.b }\end{array}$ & $\begin{array}{l}\text { Lines } 54 \\
\text { and } 68\end{array}$ & $\begin{array}{l}\text { Unabated efficiency } \\
\text { and CCS / self-use } \\
\text { load of coal with post- } \\
\text { combustion CCS, \% }\end{array}$ & $\begin{array}{l}\text { Overall efficiency of } \\
\text { coal with post- } \\
\text { combustion CCS }\end{array}$ \\
\hline $\begin{array}{l}\text { Biomass / coal power } \\
\text { stations, I.a }\end{array}$ & $\begin{array}{l}\text { Lines } 59 \\
\text { and } 52\end{array}$ & $\begin{array}{l}\text { Thermal efficiency and } \\
\text { self-use of coal \& } \\
\text { biomass power, } \%\end{array}$ & $\begin{array}{l}\text { Overall efficiency of } \\
\text { oil-fired generation }\end{array}$ \\
\hline $\begin{array}{l}\text { Electricity storage, } \\
\text { demand shifting, } \\
\text { interconnection, VII.c }\end{array}$ & Line 154 & $\begin{array}{l}\text { Thermal efficiency of } \\
\text { gas-fired OCGT } \\
\text { without CCS, } \%\end{array}$ & $\begin{array}{l}\text { Efficiency of gas } \\
\text { OCGT power stations }\end{array}$ \\
\hline $\begin{array}{l}\text { Industrial processes } \\
\text { XI.a }\end{array}$ & Line 241 & $\begin{array}{l}\text { Solid hydrocarbons } \\
\text { used, TWh }\end{array}$ & $\begin{array}{l}\text { Coal used in industry } \\
\text { excluding electricity }\end{array}$ \\
\hline $\begin{array}{l}\text { Indigenous fossil fuel } \\
\text { production XV.b }\end{array}$ & 146 & $\begin{array}{l}\text { Solid hydrocarbons in } \\
\text { coal production, TWh }\end{array}$ & $\begin{array}{l}\text { Self-use of coal by the } \\
\text { coal industry }\end{array}$ \\
\hline Agriculture, VI.a & Line 537 & $\begin{array}{l}\text { Solid hydrocarbons in } \\
\text { agriculture, TWh }\end{array}$ & $\begin{array}{l}\text { Coal used in } \\
\text { agriculture }\end{array}$ \\
\hline Agriculture, VI.a & Line 538 & $\begin{array}{l}\text { Liquid hydrocarbons in } \\
\text { agriculture, TWh }\end{array}$ & $\begin{array}{l}\text { Oil products used in } \\
\text { agriculture }\end{array}$ \\
\hline $\begin{array}{l}\text { Industrial processes } \\
\text { XI.a }\end{array}$ & Line 441 & $\begin{array}{l}\text { Gaseous } \\
\text { hydrocarbons, TWh }\end{array}$ & $\begin{array}{l}\text { Gas used in industry } \\
\text { excluding electricity }\end{array}$ \\
\hline $\begin{array}{l}\text { Petroleum refineries, } \\
\text { XV.a }\end{array}$ & $\begin{array}{l}\text { Line } 174 \text { or } \\
\text { line } 134\end{array}$ & $\begin{array}{l}\text { Gaseous } \\
\text { hydrocarbons, TWh }\end{array}$ & $\begin{array}{l}\text { Natural gas used in } \\
\text { refineries }\end{array}$ \\
\hline $\begin{array}{l}\text { Indigenous fossil fuel } \\
\text { production } X V . b\end{array}$ & Line 210 & $\begin{array}{l}\text { Gaseous } \\
\text { hydrocarbons, TWh }\end{array}$ & $\begin{array}{l}\text { Natural gas used in } \\
\text { fossil fuel extraction }\end{array}$ \\
\hline Agriculture, VI.a & Line 436 & $\begin{array}{l}\text { Gaseous } \\
\text { hydrocarbons, TWh }\end{array}$ & $\begin{array}{l}\text { Natural gas used in } \\
\text { agriculture }\end{array}$ \\
\hline $\begin{array}{l}\text { Hydrogen production } \\
\text { for transport, VIII.a }\end{array}$ & Line 17 & $\begin{array}{l}\text { Efficiency of } \\
\text { centralised steam } \\
\text { methane reformation }\end{array}$ & $\begin{array}{l}\text { Efficiency of SMR. } \\
\text { Assume all SMR will } \\
\text { be large scale. }\end{array}$ \\
\hline $\begin{array}{l}\text { Types of fuel from } \\
\text { biomass, V.a }\end{array}$ & Line 241 & $\begin{array}{l}\text { Biomass to liquid fuel } \\
\text { conversion efficiency }\end{array}$ & Not yet used in FESA \\
\hline $\begin{array}{l}\text { Types of fuel from } \\
\text { biomass, V.a }\end{array}$ & Line 245 & $\begin{array}{l}\text { Biomass to gaseous } \\
\text { fuel efficiency }\end{array}$ & Not yet used in FESA \\
\hline $\begin{array}{l}\text { Constants (Vector of } \\
\text { emissions factors) }\end{array}$ & Cell D80 & $\begin{array}{l}\text { CO2 emissions of } \\
\text { natural gas }\end{array}$ & $\begin{array}{l}\text { Natural gas emissions } \\
\text { rate }\end{array}$ \\
\hline Constants (Vector of & Cell D79 & CO2 emissions of oil & Liquid fuels emissions \\
\hline
\end{tabular}




\begin{tabular}{|l|l|l|l|}
\hline emissions factors) & and oil products & rate \\
\hline $\begin{array}{l}\text { Constants (Vector of } \\
\text { emissions factors) }\end{array}$ & Cell D78 & $\begin{array}{l}\text { CO2 emissions of coal } \\
\text { and fossil waste }\end{array}$ & $\begin{array}{l}\text { Solid fuels emissions } \\
\text { rate }\end{array}$ \\
\hline $\begin{array}{l}\text { Carbon capture and } \\
\text { storage, I.b }\end{array}$ & Line 82 & $\begin{array}{l}\text { Emissions reduction } \\
\text { due to CCS, \% }\end{array}$ & $\begin{array}{l}\text { Capturable fraction of } \\
\text { CO2 emissions from } \\
\text { point sources }\end{array}$ \\
\hline $\begin{array}{l}\text { Indigenous fossil fuel } \\
\text { production XV.b }\end{array}$ & Line 150 & Oil production & UK oil production \\
\hline $\begin{array}{l}\text { Indigenous fossil fuel } \\
\text { production XV.b }\end{array}$ & Line 151 & Gas production & UK gas production \\
\hline $\begin{array}{l}\text { Indigenous fossil fuel } \\
\text { production XV.b }\end{array}$ & Line 144 & Coal production & UK coal production \\
\hline $\begin{array}{l}\text { Types of fuel from } \\
\text { biomass, V.a }\end{array}$ & Line 385 & $\begin{array}{l}\text { Gaseous } \\
\text { hydrocarbons, TWh }\end{array}$ & $\begin{array}{l}\text { Gas produced from } \\
\text { biomass }\end{array}$ \\
\hline $\begin{array}{l}\text { Types of fuel from } \\
\text { biomass, V.a }\end{array}$ & Line 384 & Liquid hydrocarbons & $\begin{array}{l}\text { Liquid fuels produced } \\
\text { from biomass }\end{array}$ \\
\hline $\begin{array}{l}\text { Bioenergy imports, } \\
\text { V.b }\end{array}$ & Line 38 & $\begin{array}{l}\text { Liquid bioenergy } \\
\text { imported, TWh }\end{array}$ & Imported liquid biofuel \\
\hline $\begin{array}{l}\text { Waste and recycling, } \\
\text { VI.b }\end{array}$ & Line 529 & $\begin{array}{l}\text { Coal and fossil waste, } \\
\text { TWh }\end{array}$ & $\begin{array}{l}\text { Solid fuel from fossil } \\
\text { and coal waste }\end{array}$ \\
\hline $\begin{array}{l}\text { Types of fuel from } \\
\text { biomass, V.a }\end{array}$ & Line 383 & $\begin{array}{l}\text { Solid hydrocarbons, } \\
\text { TWh }\end{array}$ & $\begin{array}{l}\text { Solid from waste and } \\
\text { energy crops }\end{array}$ \\
\hline $\begin{array}{l}\text { Bioenergy imports, } \\
\text { V.b }\end{array}$ & Line 29 & $\begin{array}{l}\text { Imported bioenergy, } \\
\text { TWh }\end{array}$ & Solid biomass imports \\
\hline
\end{tabular}

